University of Nebraska - Lincoln

DigitalCommons@University of Nebraska - Lincoln

\title{
Temporal patterns and controls on runoff magnitude and solution chemistry of urban catchments in the semiarid southwestern United States
}

\author{
Erika L. Gallo \\ University of Arizona, elgallo@hwr.arizona.edu \\ Paul D. Brooks \\ University of Arizona, paul.brooks@utah.edu \\ Kathleen A. Lohse \\ Idaho State University \\ Jean E. T. McLain \\ University of Arizona
}

Follow this and additional works at: https://digitalcommons.unl.edu/usdaarsfacpub

Gallo, Erika L.; Brooks, Paul D.; Lohse, Kathleen A.; and McLain, Jean E. T., "Temporal patterns and controls on runoff magnitude and solution chemistry of urban catchments in the semiarid southwestern United States" (2013). Publications from USDA-ARS / UNL Faculty. 1249.

https://digitalcommons.unl.edu/usdaarsfacpub/1249

This Article is brought to you for free and open access by the U.S. Department of Agriculture: Agricultural Research Service, Lincoln, Nebraska at DigitalCommons@University of Nebraska - Lincoln. It has been accepted for inclusion in Publications from USDA-ARS / UNL Faculty by an authorized administrator of DigitalCommons@University of Nebraska - Lincoln. 


\title{
Temporal patterns and controls on runoff magnitude and solution chemistry of urban catchments in the semiarid southwestern United States
}

\author{
Erika L. Gallo, ${ }^{1,2 *}$ Paul D. Brooks, ${ }^{1}$ Kathleen A. Lohse ${ }^{2,3}$ and Jean E. T. McLain ${ }^{4,5}$ \\ ${ }^{1}$ Department of Hydrology and Water Resources, University of Arizona, Tucson, AZ, 85721, USA \\ 2 Department of Biological Sciences, Idaho State University, Pocatello, ID, 83209-8007, USA \\ 3 School of Natural Resources and the Environment, University of Arizona, Tucson, AZ, 85721, USA \\ ${ }^{4}$ USDA-ARS, US Arid-Land Agricultural Research Center, Maricopa, AZ, 85138, USA \\ ${ }^{5}$ Water Resources Research Center, University of Arizona, Tucson, AZ, 85719, USA
}

\begin{abstract}
:
Urban expansion and the scarcity of water supplies in arid and semiarid regions have increased the importance of urban runoff to localized water resources. However, urban catchment responses to precipitation are poorly understood in semiarid regions where intense rainfall often results in large runoff events during the short summer monsoon season. To evaluate how urban runoff quantity and quality respond to rainfall magnitude and timing, we collected stream stage data and runoff samples throughout the 2007 and 2008 summer monsoons from four ephemeral drainages in Tucson, Arizona. Antecedent rainfall explained 20\% to 30\% of discharge $(\mathrm{mm})$ and runoff ratio in the least impervious $(22 \%)$ catchment but was not statistically related to hydrologic responses at more impervious sites. Regression models indicated that rainfall depth, imperviousness and their combined effect control discharge and runoff ratios $\left(p<0.01, r^{2}=0.91\right.$ and 0.75 , respectively). In contrast, runoff quality did not vary with imperviousness or catchment size. Rainfall depth and duration, time since antecedent rainfall and event and cumulative discharge controlled runoff hydrochemistry and resulted in five specific solute response patterns: (i) strong event and seasonal solute mobilization (solute flush), (ii) event chemostasis and strong seasonal flush, (iii) event chemostasis and weak seasonal flush, (iv) event and seasonal chemostasis and (v) late seasonal flush. Our results indicate that hydrologic responses of semiarid catchments are controlled by rainfall partitioning at the event scale, whereas wetting magnitude, frequency and timing alter solute stores readily available for transport and control temporal runoff quality. Copyright @ 2012 John Wiley \& Sons, Ltd.
\end{abstract}

KEY WORDS urban; runoff; semiarid; water quality; runoff ratio

Received 28 September 2010; Accepted 12 January 2012

\section{INTRODUCTION}

Programs such as the Nationwide Urban Runoff Program (Athayde et al., 1983), the National Stormwater Quality Database (Pitt et al., 2008) and an extensive body of research (e.g. Brabec et al., 2002; Maestre and Pitt, 2006; Wenger et al., 2009) have advanced our understanding of how urbanization alters runoff quantity and quality. Despite these advances nationally, little attention has been paid to how urbanization affects storm runoff quantity and quality in arid and semiarid catchments. Efforts in these regions largely have focused on describing runoff characteristics across urban land cover types (e.g. Maestre and Pitt, 2006; Tiefenthaler et al., 2008), and few studies have addressed the seasonal variability of runoff quantity and quality (e.g. Lee $e t$ al., 2004), which is of particular importance in arid and semiarid regions where water resources are limited, streamflows are episodic and urban runoff is increasingly viewed as a renewable water resource. Given that arid and semiarid regions are experiencing some of the fastest urban

*Correspondence to: Erika L. Gallo, Department of Hydrology and Water Resources, University of Arizona, Tucson, AZ 85721, USA.

E-mail: elgallo@hwr.arizona.edu growth (Berling-Wolff and Wu, 2004; Norman et al., 2009) and may be facing increased aridity and increased variability in rainfall (Seager et al., 2007; Serrat-Capdevila et al., 2007), understanding how the seasonal variability of rainfall affects runoff and water quality will be critical for managing future water resources.

The importance of 'focused urban runoff recharge' as a renewable water resource has increased in recent years in arid and semiarid regions (Decook and Foster, 1984; Chralowicz et al., 2001; City of Santa Clara, 2011). It is well established that urbanization increases runoff magnitude and duration, decreases time to concentration and increases water yields (Paul and Meyer, 2001; Walsh et al., 2005; Maestre and Pitt, 2006; Kennedy, 2007; Shaver et al., 2007). It is also established that ephemeral waterways, in addition to mountain front and mountain block recharge, are areas of focused runoff infiltration, making stream channel losses an important groundwater recharge pathway in arid and semiarid regions (Eastoe et al., 2004; Goodrich et al., 2004; Pool, 2005; Blasch et al., 2006; Scanlon et al., 2006; Coes and Pool, 2007). Therefore, by increasing the magnitude of runoff and streamflow, urbanization in arid and semiarid regions may enhance ephemeral channel losses and groundwater recharge and subsequently augment renewable 
groundwater resources. However, increasing the magnitude of runoff and streamflow from urban areas may also increase the delivery of contaminants to areas of focused recharge (Fischer et al., 2003; Carlson et al., 2011).

A substantial number of studies indicate that stream water quality decreases as urbanization increases (e.g. Walsh et al., 2005; Rose, 2007). Early stormwater studies and monitoring efforts focused on the role of land use as the primary control of runoff quality (Klein, 1979; Heaney and Huber, 1984). However, findings from extensive national stormwater monitoring programs, such as the Nationwide Urban Runoff Program and the National Stormwater Quality Database, suggest that the characteristics of the regional rainfall regime impart a stronger effect on stormwater quality than land use alone (Athayde et al., 1983; Pitt et al., 2008). The effects of rainfall characteristics in controlling urban runoff quality, solute sourcing and transport have received little attention in arid and semiarid regions where rainfall is episodic. Several studies indicate that solute flushing from semiarid uplands and hill slopes in response to summertime rainfall result in elevated streamflow solute concentrations (Parks and Baker, 1997; Brooks et al., 2007; Harms and Grimm, 2010). In addition, positive correlations between solute concentrations in runoff, antecedent dry days and rainfall characteristics have been identified in both, semiarid urban and nonurban systems (Ishaq and Alassar, 1999; Westerhoff and Anning, 2000; Welter et al., 2005; Lewis and Grimm, 2007), suggesting that solute sourcing, retention and transport are controlled by the frequency and magnitude of wetting (Welter et al., 2005; Harms and Grimm, 2010).

Given that the temporal distribution of rainfall may control catchment hydrologic and hydrochemical responses in semiarid regions, in this study, we ask: How do urban runoff quantity and quality vary throughout the summer monsoon and what are the controlling mechanisms? Here we examine monsoonal urban runoff quantity and quality of four urbanized catchments in Tucson, Arizona. We expected that runoff quantity would increase with impervious cover, rainfall magnitude and cumulative rainfall, whereas solute concentrations in runoff would vary inversely with rainfall and discharge magnitude and decrease as the summer monsoon progressed.

\section{STUDY REGION OVERVIEW AND STUDY PERIOD}

The study sites are located within an alluvium-filled valley in the Basin and Range region of southern Arizona and form part of the Tucson Metropolitan area, which is bounded by the Santa Catalina Mountains to the north, the Rincon Mountains to the east and the Tucson Mountains to the west. The study sites drain to Rillito Creek (Figure 1), which along with the Santa Cruz River and its major tributaries, Canada del Oro, Pantano Wash and Tanque Verde Creek, flow intermittently towards the northwest (Wilson et al., 1998). Because these major ephemeral waterways have been identified as areas of focused groundwater recharge, they are particularly important for localized water resources conservation and management. Intense groundwater mining to support agriculture and urban growth has lowered the water table up to $61 \mathrm{~m}$ in areas of the basin's central well field, shifting the streamflow regime of the basin waterways from perennial to ephemeral (Wilson et al., 1998; Gelt et al., 1999).

The mean annual temperature and precipitation in the Tucson Basin are $20.2^{\circ} \mathrm{C}$ and $310 \mathrm{~mm}$, respectively. The climate is semiarid with an annual potential evaporation of $1960 \mathrm{~mm}$, six times more than the mean annual precipitation (Wilson et al., 1998; Gelt et al., 1999), whereas annual evapotranspiration can exceed $250 \mathrm{~mm}$ (Unland et al., 1996). Precipitation is distributed bimodally with approximately $48 \%$ of rainfall occurring during the summer months and $52 \%$ occurring in the winter (Gelt et al., 1999). Summer monsoonal rainfall events are short in duration, high in intensity, spatially heterogeneous and follow an extended period of hot and dry conditions and are driven by atmospheric convection (Gelt et al., 1999; Hoffmann et al., 2007; Renard et al., 2008; Stone et al., 2008). Summertime storms generate a larger fraction of annual runoff than winter precipitation events (Goodrich et al., 2008; Stone et al., 2008), which are colder, of lower intensity and longer duration. This study was conducted during the 2007 and 2008 summer monsoons, which officially span the period between 15 June and 30 September (Guido, 2008). The Tucson Basin received approximately 172.2 and $242.8 \mathrm{~mm}$ of rainfall during the 2007 and 2008 monsoon, respectively.

\section{METHODS}

\section{Catchment characterization}

We used surface topography and stormwater drainage system data provided by the City of Tucson's Office of Conservation and Sustainable Development to select study sites that are hydrologically contiguous and isolated from adjacent catchments. The selected catchments captured a range of urban catchment sizes, slopes, orientations and land uses typical of the Tucson Basin (Gallo et al., in revision). In brief, percent impervious cover (IC; imperviousness henceforth) was $22 \%, 41 \%, 46 \%$ and $91 \%$ in the low-density (LD), medium-density (MD), mixed (MX) and commercial (CM) catchment, respectively, and was calculated as

$$
\mathrm{IC}=\frac{100}{a_{\mathrm{c}}} \cdot \sum_{x=i}^{n} a_{\mathrm{LC} x} \cdot f \mathrm{IC}_{\mathrm{LC} x}
$$

where $a_{\mathrm{c}}$ is the catchment size or area in square kilometers and $a_{\mathrm{LC} x}$ is the area in square kilometers of land cover $x$, which were calculated in ArcMap 9.0 using the default 'Area Calculation by Gauss' method, and $f \mathrm{IC}_{\mathrm{LC} x}$ is the fraction of the imperviousness of land cover $x$ obtained from the City of Tucson's Office of Conservation and Sustainable Development. Here we do not use the 2001 National Land Cover Database imperviousness product because large parcels that were not urbanized in 2002 had been developed by 2005. Other catchment descriptions such 


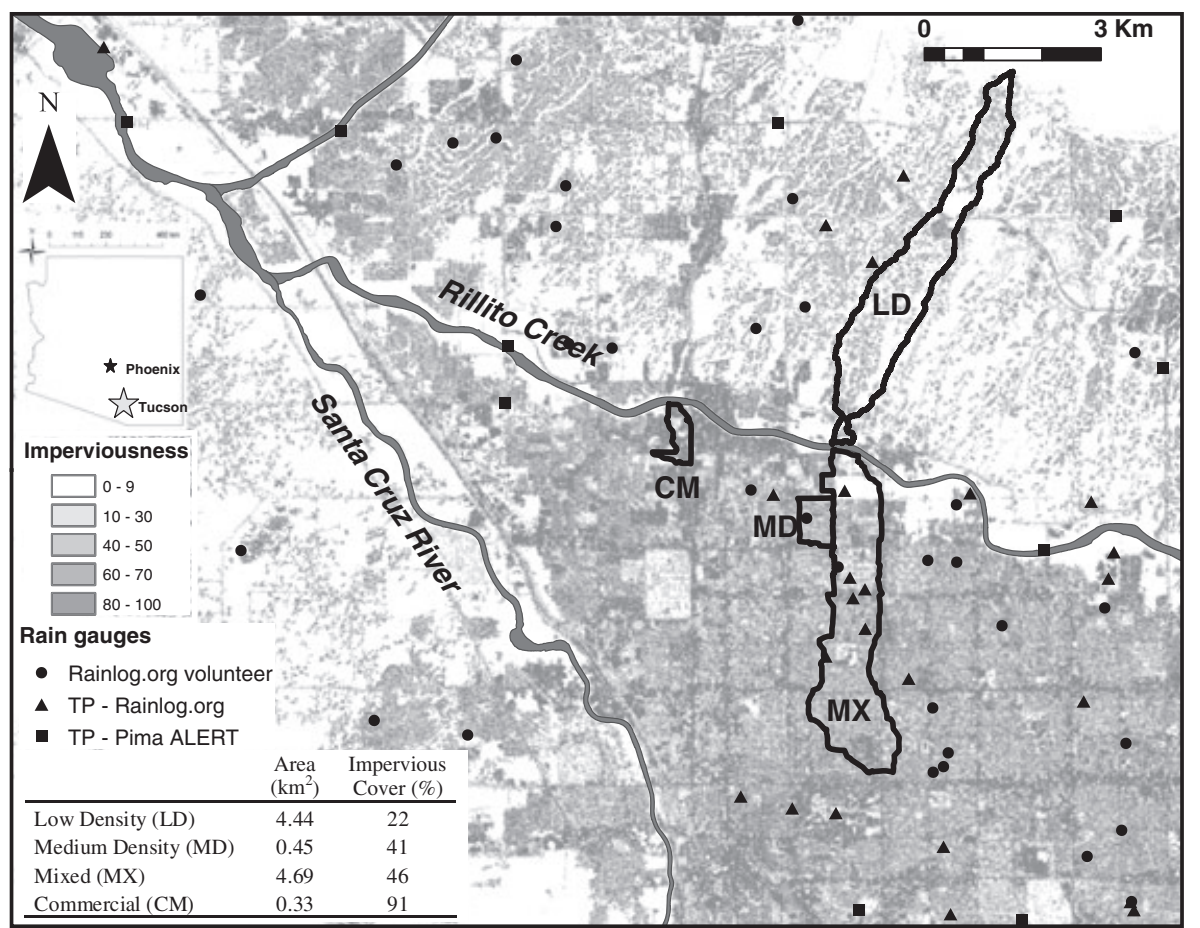

Figure 1. Location and major characteristics of our five study sites in the Tucson Basin and of rain gauges used to quantify precipitation in the study. All catchments drain untreated storm runoff to Rillito Creek, a major ephemeral wash. The catchments span a range of sizes $\left(0.32-4.69 \mathrm{~km}^{2}\right)$ and impervious

covers $(22 \%-91 \%)$. Black circles denote locations of manual rain gauges, triangles and squares denote location of tipping bucket rain gauges

as channel substrate characteristics and land use can be found in the work of Gallo et al. (in revision).

\section{Monsoonal rainfall}

The spatial distribution of monsoonal precipitation in the Southwest is highly variable (Comrie and Broyles, 2002; Goodrich et al., 2008; Renard et al., 2008), and most summertime rain days receive only one precipitation pulse. Although radar rainfall products exist, they tend to underestimate convective rainfall depth and overestimate rainfall duration (Xie et al., 2006). Therefore, to calculate rainfall depth in millimeters $\left(P_{\text {depth }}\right)$ for any given rainfall event at each site during the study period, we used an inverse distance weighted method as outlined by Garcia et al. (2008) to interpolate spatially distributed precipitation point data obtained from Rainlog.org (http://rainlog. org) and the Pima County Regional Flood Control District Automated Local Evaluation in Real Time (ALERT) System (http://www.rfcd.pima.gov/wrd/alertsys/index. htm; Figure 1). Several rainfall monitoring sites within our study catchments were also equipped with Rainlog.org tipping bucket rain gauges or were located near the ALERT System tipping buckets. Therefore, we used Rainlog.org and ALERT System tipping bucket rain gauge data (tipping resolutions of 2.54 and $1 \mathrm{~mm}$, respectively) to calculate (i) rainfall duration $\left(P_{\text {duration }}\right)$ in hours, (ii) time since antecedent rainfall or time since last rain in days and (iii) the fraction of rainfall that precipitated during each rainfall pulse on the few days when more than one rainfall event was observed. Some studies indicate that under very high and very low rainfall intensity tipping, buckets may underestimate $P_{\text {depth }}$ (e.g. Ciach, 2003). To generate a spatially weighted catchment wide rainfall intensity ( $\left.P_{\text {intensity }}\right)$ estimates, we calculated $P_{\text {intensity }}$ by dividing $P_{\text {depth }}$ by $P_{\text {duration. }}$. Antecedent rainfall depth, duration and intensity refer to the $P_{\text {depth }}, P_{\text {duration }}$ and $P_{\text {intensity }}$ of the prior rainfall event. Cumulative rainfall over the duration of the monsoon was calculated by adding the depths of all monsoonal rainfall events.

\section{Discharge and runoff ratio}

We installed pressure transducers (Submerged Flow Module 720, Teledyne Technologies, Lincoln, Nebraska, stage accuracy $\pm 0.3 \mathrm{~cm}$ ) along stable cross sections at the outlet of each catchment to record stage data every minute. We calculated instantaneous discharge $\left(Q_{t}\right)$ in liters per second using Manning's equation (ASCE, 1996):

$$
Q_{t}=A \frac{1000}{n} R_{h}^{2 / 3} s^{1 / 2}
$$

where $A$ is the cross-sectional area of flow within the channel in $\mathrm{m}^{2}, n$ is the channel roughness coefficient, $R_{h}$ is the hydraulic radius in meters and $s$ is the energy slope. The energy slope was assumed to be approximately equal to the bed slope. We chose a Manning's approach because of the lack of pre-existing discharge data at these sites and because generating rating curves presented itself as a physical hazard because of the flash flood conditions that accompany monsoonal stream flow. On the basis of the channel substrate, we used $n$ values of 0.025 for earthen channels at LD and MX, 0.013 for a concrete lined channel at CM and 0.024 for a corrugated metal pipe at MD (ASCE, 1996). Owing to data losses during download, we present discharge data for three of our four sites for 2007. 
Event discharge depth in millimeters $(Q$, discharge henceforth) was calculated as

$$
Q=\frac{6 \times 10^{-5}}{a_{\mathrm{c}}} \cdot \sum_{t=0}^{i} Q_{t}
$$

where $6.0 \times 10^{-5}$ is a conversion factor with units of seconds per cubic millimeter. The event runoff ratio has units of percentage of $P_{\text {depth }}$, calculated by dividing discharge by $P_{\text {depth }}$ and multiplying by 100 . Monsoonal discharge accumulated up to and including runoff event $i$ (CQ, cumulative discharge henceforth) was calculated as

$$
C Q=\sum_{i=1}^{i} Q_{i}
$$

Total cumulative monsoonal discharge $\left(\mathrm{CQ}_{\mathrm{tot}}\right)$ at each site per year was calculated by adding the discharge depth of all monsoonal runoff events. Normalized cumulative monsoonal discharge for each event (NCQ) was calculated as the ratio of $C Q$ to $\mathrm{CQ}_{\text {tot }}$.

\section{Runoff sample collection}

Runoff samples were collected every $20 \mathrm{~min}$ for up to $4 \mathrm{~h}$ in clean acid washed, combusted $\left(500^{\circ} \mathrm{C}\right.$ for $\left.3 \mathrm{~h}\right) 1-1$ glass bottles using automatic samplers (Teledyne ISCO 6712, Lincoln, NE) with Teflon ${ }^{\circledR}$ tubing installed at the outlet of each catchment. An additional uncapped bottle was added as a control blank, which was filled with deionized water and processed in the same way as the runoff samples. The samples were capped with Teflon caps, placed in dark chilled $\left(\sim 4{ }^{\circ} \mathrm{C}\right)$ coolers and immediately transported to the University of Arizona for processing.

\section{Laboratory analysis and solute load calculations}

Sample aliquots for bacterial analyses were immediately poured off into sterile 250-ml HDPE bottles and shipped overnight on ice to the USDA-ARS in Maricopa, Arizona. All other aliquots were filtered within $24 \mathrm{~h}$ of sample collection and stored at $4{ }^{\circ} \mathrm{C}$ with the exception of aliquots for metal analysis, which were stored at room temperature. Sample aliquots for nutrient analysis, including ammonium-nitrogen $\left(\mathrm{NH}_{4}-\mathrm{N}\right)$, orthophosphatephosphorous $\left(\mathrm{PO}_{4}-\mathrm{P}\right)$, dissolved organic carbon (DOC) and total dissolved nitrogen (TDN), were filtered through precombusted $0.7-\mu \mathrm{m}$ glass fiber filters (Whatman GF/F) and stored in clean precombusted amber glass bottles with Teflon-lined caps. Aliquots for anion, cation and metal analyses were filtered through $0.45-\mu \mathrm{m}$ membrane filters (Millipore MF). Analysis of $\mathrm{NH}_{4}-\mathrm{N}$ and $\mathrm{PO}_{4}-\mathrm{P}$ were performed on a SmartChem Discrete Analyzer (Westco Scientific, Brookfield, CT) with detection limit (DL) of 0.002 and $0.001 \mathrm{mgl}^{-1}$ for $\mathrm{NH}_{4}-\mathrm{N}$ and $\mathrm{PO}_{4}-\mathrm{P}$, respectively. Dissolved organic carbon and TDN analyses were performed on a Shimatzu TOC/TN Analyzer (Shimadzu, Columbia, MD) with a method DL of $0.05 \mathrm{mg} \mathrm{l}^{-1}$ for DOC and $0.05 \mathrm{mg}^{-1}$ for TDN. Anions $\left(\mathrm{Cl}\right.$, nitrate- $\mathrm{N}\left(\mathrm{NO}_{3}-\mathrm{N}\right)$, nitrite- $\mathrm{N}\left(\mathrm{NO}_{2}-\mathrm{N}\right)$ and sulfate- $\left.\mathrm{S}\left(\mathrm{SO}_{4}-\mathrm{S}\right)\right)$ were analyzed in a
Dionex Ion Chromatograph (ICS-3000, DIONEX, San Jose, CA) with an AS23 column (DL $=0.05 \mathrm{mg}^{-1}$ ). Dissolved organic nitrogen (DON) was calculated by subtracting $\mathrm{NO}_{3}-\mathrm{N}, \mathrm{NO}_{2}-\mathrm{N}$ and $\mathrm{NH}_{4}-\mathrm{N}$ from TDN. Base cations (calcium $(\mathrm{Ca})$, sodium $(\mathrm{Na})$, magnesium $(\mathrm{Mg})$, potassium $(\mathrm{K})$ ) and metals (lead $(\mathrm{Pb})$, zinc $(\mathrm{Zn})$, iron $(\mathrm{Fe})$, copper $(\mathrm{Cu})$, cobalt $(\mathrm{Co})$, nickel $(\mathrm{Ni})$, aluminium $(\mathrm{Al})$, manganese $(\mathrm{Mn})$, vanadium $(\mathrm{V})$, cadmium $(\mathrm{Cd})$, arsenic (As) and mercury $(\mathrm{Hg})$ ) were analyzed on an inductively coupled plasma mass spectrometer (Elan DRC-II ICP-MS, $\mathrm{DL}=0.001 \mu \mathrm{g}^{-1}$ ) using sample aliquots stored in precleaned glass bottles with Teflon caps and preserved with nitric acid $\left(\mathrm{HNO}_{3}\right)$ to approximately $1 \%$ and $\mathrm{pH} 2$ to 3 . Escherichia coli analyses followed US Environmental Protection Agency method 1604 (EPA, 2002). Duplicates of two sample dilutions $(1.0$ and $0.1 \mathrm{ml})$ were passed through a $0.45-\mu \mathrm{m}$ sterile filter to retain bacteria, plated in BBL $^{\mathrm{TM}}$ MI agar (Becton, Dickinson and Co.), supplemented with $5 \mu \mathrm{g} \mathrm{ml}^{-1}$ of cefsulodin to inhibit Gram-positive bacterial growth and incubated at $35^{\circ} \mathrm{C}$ for $24 \mathrm{~h}$. Blue or indigo colonies were counted as presumptive for $E$. coli.

Solute loads for each runoff event $\left(L_{e}\right)$ were calculated as

$$
L_{\mathrm{e}}=60 \sum_{t=1}^{n} c_{\mathrm{t}} \cdot Q_{\mathrm{t}}
$$

where 60 has units of seconds and $c_{\mathrm{t}}$ is the solute concentration in mass per liter. Linear interpolation was used to calculate $c_{\mathrm{t}}$ between two measured data points. Monsoonal loads accumulated up to and including runoff event $L_{e}\left(\mathrm{CL}_{\mathrm{e}}\right)$ were calculated as

$$
\mathrm{CL}_{\mathrm{e}}=\sum_{i=1}^{i} L_{e i}
$$

The $\mathrm{CL}_{\mathrm{e}}$ for each solute at each site for each year were summed to calculate the total cumulative monsoonal load $\left(\mathrm{CL}_{\text {tot }}\right)$. The normalized cumulative monsoonal load (NCL) for each event refers to the ratio of $\mathrm{CL}_{\mathrm{e}}$ to $\mathrm{CL}_{\mathrm{tot}}$.

\section{Statistical analysis of rainfall-runoff}

Statistical analyses of rainfall-runoff and runoff quality were performed using JMP 8.0.2 (JMP ${ }^{\circledR}$, Version 8.0.2. SAS Institute Inc., Cary, NC, 1989-2009). Data were log transformed before analysis to normalize the distribution of the variance in our data set (Driver and Troutman, 1989). To determine whether rainfall characteristics were significantly different between water years and among sites, we performed mean $t$-tests across water years and Tukey-Kramer comparison of means across sites on the total number of rainfall events, cumulative rainfall, $P_{\text {depth }}$, $P_{\text {duration, }} P_{\text {intensity, time since antecedent rainfall and }}$ antecedent rainfall depth, duration and intensity. To identify whether discharge and runoff ratios varied over the monsoon, we regressed discharge and runoff ratios versus day of year and cumulative rainfall. We also used linear regression to determine if discharge and runoff 
ratios varied with imperviousness, catchment size or any other rainfall characteristic across sites. To determine how discharge and runoff ratios relate to rainfall characteristics at each site, we regressed discharge and runoff ratios against day of year, cumulative rainfall, $P_{\text {depth }}, P_{\text {intensity }}$, $P_{\text {duration }}$, time since antecedent rainfall and antecedent rainfall conditions. On the basis of the correlation analysis, we generated a two-component regression model for discharge and runoff ratios that included the multiplicative effects of rainfall characteristics with imperviousness and catchment size.

\section{Statistical analysis of runoff quality}

To identify how solute concentrations changed over the season, we regressed mean event concentrations (solute concentrations henceforth) versus day of year and cumulative rainfall. For further statistical analyses, solute concentrations, discharge, cumulative discharge and all rainfall characteristics were $\log$-transformed to linearize power relationships and to normalize the distribution of our data (Edwards, 1973; Godsey et al., 2009). We assessed the effect of rainfall and runoff characteristics and timing on runoff solute hydrochemistry by calculating the coefficient of correlation $(r)$ of solute concentrations against discharge, cumulative discharge, runoff ratios, $P_{\text {depth }}, P_{\text {duration }}, P_{\text {intensity }}$, time since antecedent rainfall, antecedent rainfall conditions, imperviousness and catchment size. Solute concentration-discharge relationships $\left(c_{e}-Q\right)$ with significant negative slopes were interpreted as solute dilution, whereas nonsignificant regressions (slope $=0$ ) were indicative of solute chemostasis (Godsey et al., 2009). Solute chemostatic conditions indicate that solute concentrations are stable and nonvariant with respect to stream discharge suggesting that discharge is not a primary control of solute dynamics (Godsey et al., 2009). We calculated the slope $(m)$ and performed $t$-tests $\left(\mathrm{H}_{\mathrm{o}}: m=1\right)$ of the NCL to normalized cumulative discharge regression (NCL-NCQ) to distinguish early seasonal flushing $(m<1)$ from late seasonal flushing $(m>1)$ and seasonal chemostasis $(m=1)$. Although this technique has been mainly used to describe event scale solute flushing patterns in urbanized catchments (Deletic, 1998; Lee et al., 2003; Obermann et al., 2009), here we have modified it similar to Lee et al. (2004) to identify seasonal solute responses.

We used a standardized Wards clustering analysis (Sall et al., 2007) on the $r$ values of each solute to rainfall, runoff and land cover variables to identify groups of solutes with similar seasonal responses. Only independent variables with more than four significant solute correlations were included in the clustering analysis. For further analysis and interpretation, we retained solute response clusters with a standardized Euclidian distance between them greater than 2.0. Finally, we use a Tukey-Kramer method to compare mean coefficients of correlation $(\bar{r})$ of the previously selected rainfall and runoff characteristics across solute clusters and test for between grouping response differences.

\section{RESULTS}

\section{Sampling period and monsoonal rainfall}

Rainfall-runoff monitoring and water quality collections spanned a large range of $P_{\text {depth }}$ and time since the onset of the monsoon over the 2 years of study (Figure 2). The 2007 monsoon had significantly $(p<0.05)$ less seasonal rainfall than the 2008 monsoon (average seasonal rainfall of 193 and $247 \mathrm{~mm}$, respectively), which can be attributed to a significantly lower number of rainfall events in 2007 than in 2008 (23.0 and 28.3 average rainfall events, respectively; Table I). Although seasonal rainfall was greater in 2008, there were no significant differences in $P_{\text {depth }}, P_{\text {intensity }}$ and $P_{\text {duration }}$ or time since antecedent rainfall between monsoon seasons, and rainfall characteristics did not vary significantly with day of year and were similar to those reported in other studies in the region (e.g. Mendez et al., 2003).
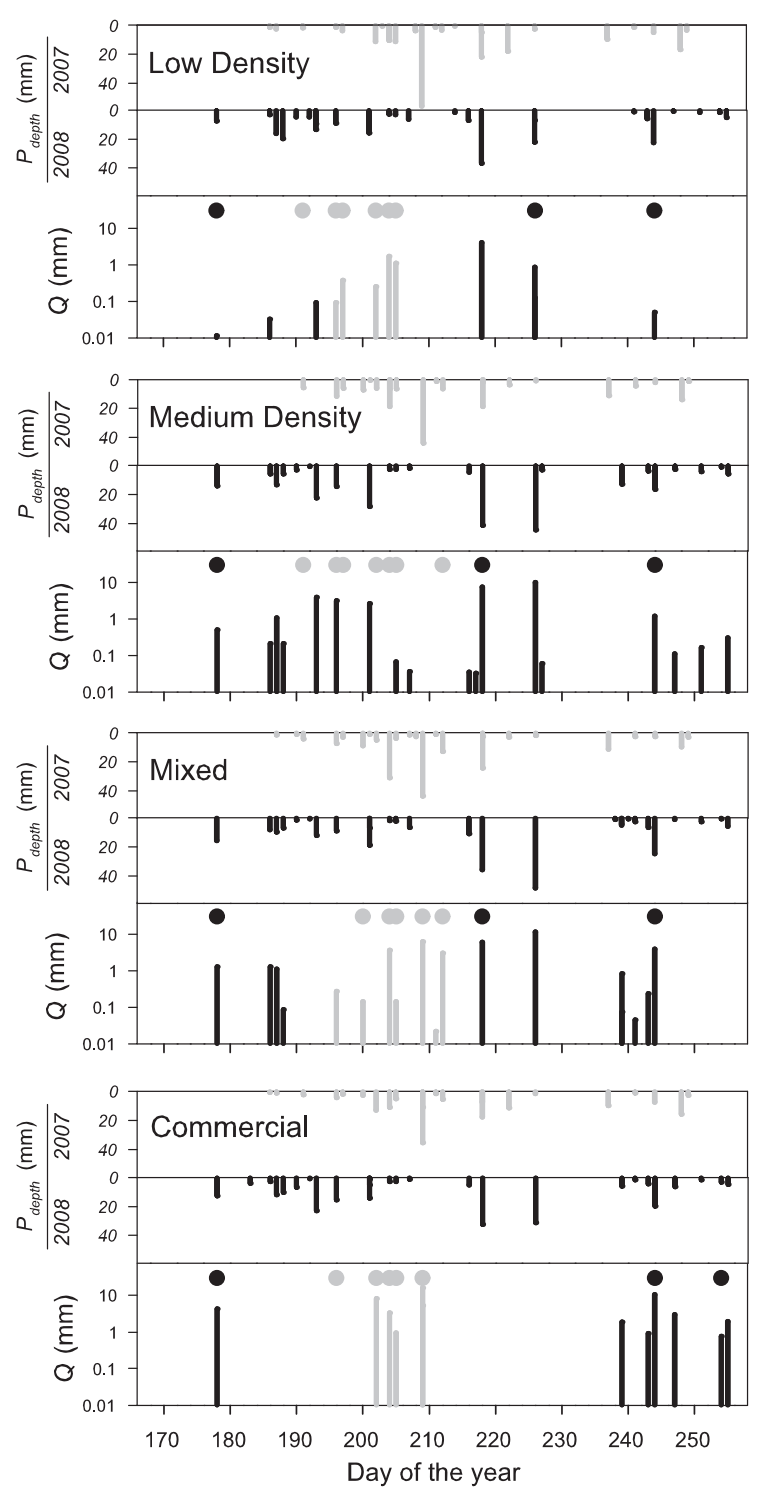

Figure 2. Rainfall hyetographs and discharge for the 2007 (gray) and 2008 (black) summer monsoons at each of our study sites. Circles indicate discharge events sampled for runoff quality. Discharge records for the Medium Density site during 2007 are not available 


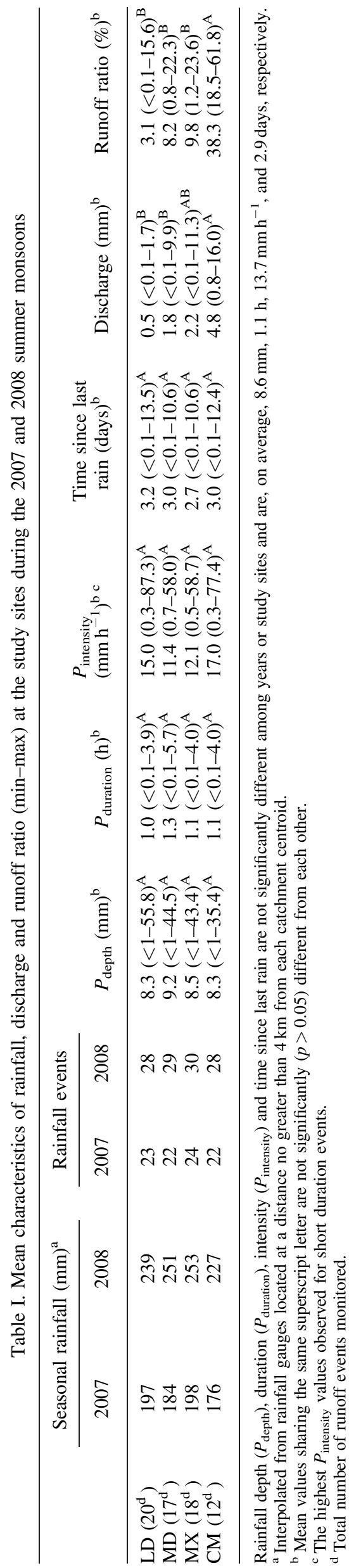

\section{Discharge and runoff ratio}

Across sites, discharge and runoff ratios did not vary significantly or predictably with day of year or cumulative rainfall. However, discharge and runoff ratios increased significantly with $P_{\text {depth }}\left(r^{2}=0.52\right.$ and 0.08 , respectively $)$, imperviousness $\left(r^{2}=0.20\right.$ and 0.65 , respectively) and antecedent rainfall duration $\left(r^{2}=0.13\right.$ and 0.12 , respectively) and decreased significantly with catchment size $\left(r^{2}=0.15\right.$ and 0.20 , respectively). Not surprisingly, discharge and runoff ratios were significantly larger at the commercial site $(\mathrm{CM})$, which has the highest imperviousness, than at all other sites (Table I). At each site, discharge and runoff ratios were most significantly correlated with $P_{\text {depth }}$ (Table II). The strongest discharge- $P_{\text {depth }}$ correlation was at $\mathrm{CM}(r=0.95)$ and the weakest at the low density (LD) site $(r=0.47)$ (Table II). Correlations of discharge and runoff ratios to $P_{\text {duration }}$ and $P_{\text {intensity }}$ were weaker than correlations with $P_{\text {depth }}$. Interestingly, discharge and runoff ratios correlated significantly with antecedent rainfall depth and duration at LD only, whereas discharge or runoff ratios did not correlate with day of year, cumulative rainfall or antecedent rainfall characteristics at any of the sites.

On the basis of the results of the discharge and runoff ratio regression analyses, we constructed multiple regression models with discharge and runoff ratio as response variables and land cover (imperviousness or catchment size), rainfall characteristics $\left(P_{\text {depth }}, P_{\text {duration }}, P_{\text {intensity }}\right.$ or antecedent rainfall duration) and interactive terms (e.g. imperviousness $\left.\times P_{\text {depth }}\right)$ as independent variables. No significant correlations between imperviousness, catchment size and rainfall characteristics were observed. Statistical models including catchment size explained a smaller fraction of the discharge and runoff ratio variance than models that included imperviousness. Of the models generated, the most robust included $P_{\text {depth }}$, imperviousness (IC) and their interaction $\left(P_{\text {depth }} \times I C\right)$ and predicted $91 \%$ of the variance in discharge and $75 \%$ of the variance in runoff ratio ( $p<0.01$; Figure 3). Removing large $P_{\text {depth }}$ values from the model returned $r^{2}$ values of 0.87 and 0.73 for discharge $(Q)$ and runoff ratio (RR), respectively, demonstrating that large $P_{\text {depth }}$ did not weigh disproportionately into the model. The regression equations are as follows:

$$
\begin{aligned}
Q= & -4.91+\left(0.23 P_{\text {depth }}\right)+(0.09 \mathrm{IC}) \\
& +\left[0.01\left(P_{\text {depth }}-13.13\right)(\mathrm{IC}-45.37)\right] \\
\mathrm{RR}= & -18.65+\left(0.39 P_{\text {depth }}\right)+(0.58 \mathrm{IC}) \\
& +\left[0.02\left(P_{\text {depth }}-13.13\right)(\mathrm{IC}-45.37)\right]
\end{aligned}
$$

The next best performing statistical model included antecedent rainfall duration, imperviousness and antecedent rainfall duration $\times$ imperviousness predicted $25 \%$ and $65 \%$ of the variance in discharge and runoff ratio, respectively. Models that included more than two independent variables (e.g. imperviousness, $P_{\text {depth }}$ and antecedent rainfall duration) did not improve the fraction of the variance explained by the statistical model. 
Table II. Coefficient of correlation and significance of fit ( $r$ and $p$ ) of discharge and runoff ratio to rainfall characteristics

\begin{tabular}{|c|c|c|c|c|c|c|}
\hline & \multirow[b]{2}{*}{ Catchment (n) } & \multirow[b]{2}{*}{$P_{\text {depth }}$} & \multirow[b]{2}{*}{$P_{\text {intensity }}$} & \multirow[b]{2}{*}{$P_{\text {duration }}$} & \multicolumn{2}{|c|}{ Antecedent rainfall } \\
\hline & & & & & intensity & duration \\
\hline \multirow[t]{4}{*}{ Discharge } & LD (20) & $0.42(0.04)$ & ns & ns & $-0.47(0.04)$ & $0.55(0.02)$ \\
\hline & MD (17) & $0.92(<0.01)$ & $0.58(0.01)$ & $0.54(0.02)$ & ns & ns \\
\hline & MX (18) & $0.92(<0.01)$ & $0.69(<0.01)$ & $0.65(0.01)$ & ns & ns \\
\hline & CM (12) & $0.95(<0.01)$ & $0.77(0.01)$ & ns & ns & ns \\
\hline \multirow[t]{4}{*}{ Runoff ratio } & LD (20) & ns & ns & ns & $-0.46(0.05)$ & $0.57(0.01)$ \\
\hline & MD (17) & $0.58(0.01)$ & ns & $0.48(0.04)$ & ns & ns \\
\hline & MX (18) & $0.70(<0.01)$ & $0.56(0.02)$ & ns & ns & ns \\
\hline & CM (12) & $0.64(<0.01)$ & ns & ns & ns & ns \\
\hline
\end{tabular}

Nonsignificant correlations $(p>0.05)$ are reported as 'ns'.

a)

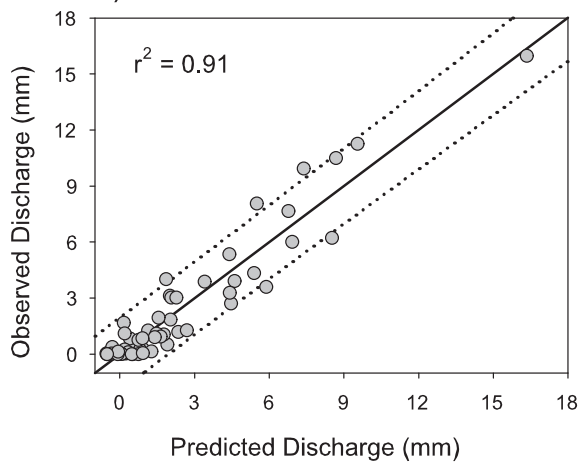

b)

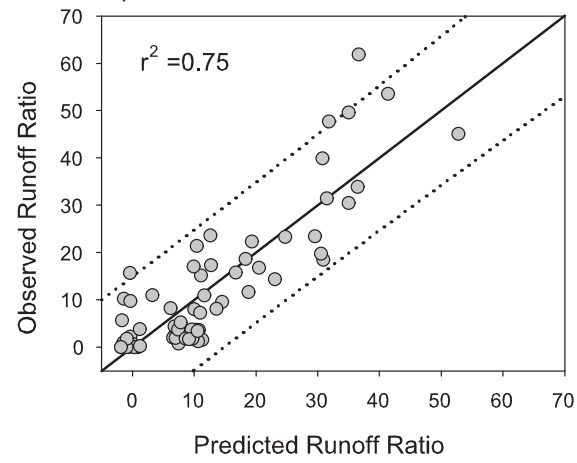

Figure 3. (a) Observed discharge versus predicted discharge and (b) observed runoff ratio versus predicted runoff ratio from a two-component least squares statistical model that includes $P_{\text {depth }}$, imperviousness and $P_{\text {depth }} \times$ imperviousness. Both models are highly significant $(p<0.01)$. Dashed lines denote the $95 \%$ prediction interval
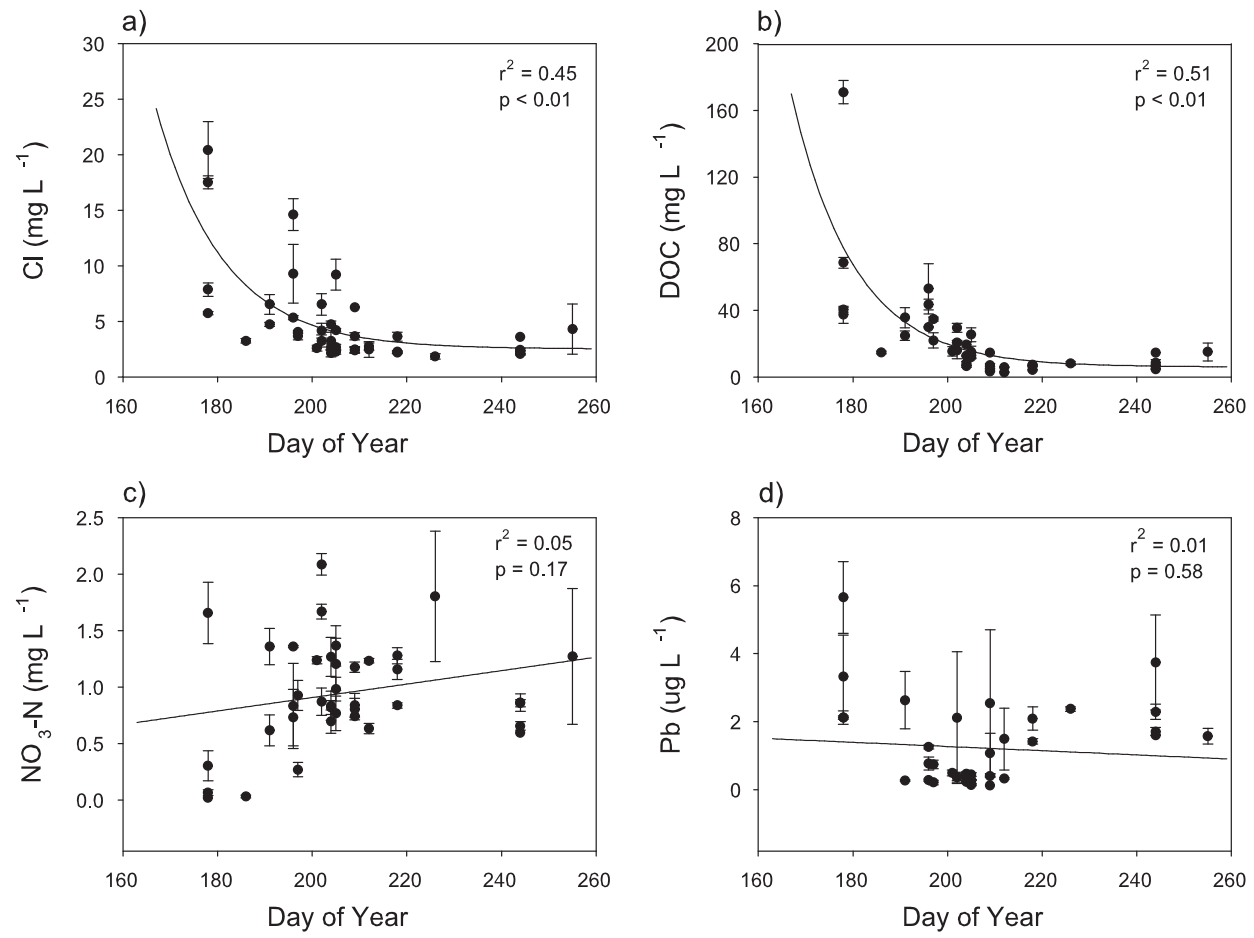

Figure 4. Mean seasonal solute concentrations of (a) $\mathrm{Cl}$, (b) DOC, (c) $\mathrm{NO}_{3}-\mathrm{N}$ and (d) $\mathrm{Pb}$ against day of the year during both the 2007 and 2008 monsoon. We observe a significant exponential decrease in $\mathrm{Cl}$ and $\mathrm{DOC}$ concentration as the monsoon progresses. In contrast, concentrations of $\mathrm{NO}_{3}-\mathrm{N}$ and $\mathrm{Pb}$ do not vary significantly over the monsoon 


\section{Solute hydrochemistry}

Most solute concentrations exhibited seasonal responses like those illustrated by $\mathrm{Cl}$ and DOC, where concentrations decreased significantly and exponentially with increasing day of year (Figures $4 \mathrm{a}$ and $4 \mathrm{~b}$ ) and cumulative rainfall. However, $\mathrm{NO}_{2}-\mathrm{N}$, E. coli and $\mathrm{PO}_{4}-\mathrm{P}$ concentrations exhibited seasonal responses similar to those illustrated by $\mathrm{NO}_{3}-\mathrm{N}$ and $\mathrm{Pb}$, which remained invariant with respect to day of year (Figures $4 \mathrm{c}$ and $4 \mathrm{~d}$ ) and cumulative rainfall.

Solute concentration responses to $P_{\text {depth }}, P_{\text {duration }}$, time since antecedent rainfall, discharge and cumulative discharge varied in their strength and direction (Table III). For example, as illustrated in Figures $5 \mathrm{a}$ and 5b, DOC significantly decreased as discharge increased, $\mathrm{NO}_{3}-\mathrm{N}$ weakly increased $(0.1>p>0.05)$ with discharge and $\mathrm{Cl}$ and $\mathrm{Pb}$ varied independently of discharge and behaved chemostatically $(m=0)$. Similarly, the $\log -\log$ regressions of solute concentration versus cumulative discharge indicate that $\mathrm{Cl}$ and DOC significantly decreased as cumulative discharge increased, $\mathrm{NO}_{3}-\mathrm{N}$ significantly increased with cumulative discharge and $\mathrm{Pb}$ behaved chemostatically (Figures 5c and 5d). Most solute concentrations $(n>19)$ significantly decreased as cumulative discharge and $P_{\text {duration }}$ increased and significantly increased as time since antecedent rainfall increased. About half the solutes significantly decreased as discharge and $P_{\text {depth }}$ increased, and most solutes did not correlate with imperviousness, catchment size (Table III), $P_{\text {intensity }}$ or antecedent rainfall depth, intensity and duration. Interestingly, E. coli did not correlate significantly with any rainfall or runoff characteristics. The NCL-NCQ analyses indicate that about half of the solutes $(n=12)$ exhibited an early season solute flush $(m<1$; Table III), for example, $\mathrm{Cl}$ and DOC (Figures 6a and 6b), whereas approximately half $(n=12)$ exhibited seasonal solute chemostasis $(m=1)$, for example, $\mathrm{NO}_{3}-\mathrm{N}$ and $\mathrm{Pb}$ (Figures $6 \mathrm{c}$ and $6 \mathrm{~d}$ ). Interestingly, $\mathrm{PO}_{4}-\mathrm{P}$ was the only solute to exhibit a late seasonal flush $(m>1)$.

Five distinct seasonal solute response patterns, clusters C1-C5, were identified with the clustering analyses (cluster distance $>2.0$; Figure 7 ). The mean correlation $(\bar{r})$ and maximum significance values of solute concentrations versus $P_{\text {depth }}, P_{\text {duration, time since ante- }}$ cedent rainfall, discharge and cumulative discharge and the mean NCL-NCQ regression slope $(\bar{m})$ for each cluster (Table IV) highlight differences in seasonal solute cluster responses to rainfall and runoff. Specifically, cluster C1 was the only cluster that was significantly and negatively

Table III. Correlations $(r)$ of mean storm solute concentrations to select rainfall and runoff characteristics, imperviousness and catchment size; and slope of normalized cumulative load to normalized cumulative discharge regression $\left(m_{\mathrm{NCL}-\mathrm{NCQ}}\right)$

\begin{tabular}{|c|c|c|c|c|c|c|c|c|}
\hline Solute & $P_{\text {depth }}{ }^{\mathrm{a}}$ & $P_{\text {duration }}{ }^{\mathrm{a}}$ & $\begin{array}{l}\text { Time since } \\
\text { last rain }\end{array}$ & $\begin{array}{l}\text { Discharge } \\
\text { depth }^{\mathrm{c}}\end{array}$ & $\begin{array}{l}\text { Cumulative } \\
\text { discharge }^{c}\end{array}$ & $\begin{array}{l}\text { Impervious } \\
\text { cover }^{\mathrm{a}}\end{array}$ & $\begin{array}{c}\text { Catchment } \\
\text { area }^{\mathrm{a}}\end{array}$ & $m_{\mathrm{NCL}-\mathrm{NCQ}}{ }^{\mathrm{c}}$ \\
\hline $\mathrm{Cl}$ & $-0.35 *$ & $-\mathbf{0 . 5 7} *$ & $0.61 *$ & -0.24 & $-0.48 *$ & $0.31 * *$ & -0.18 & $0.90 *$ \\
\hline $\mathrm{NO}_{2}-\mathrm{N}$ & -0.27 & 0.06 & $0.34 *$ & -0.01 & -0.13 & 0.09 & -0.03 & $0.90 * *$ \\
\hline $\mathrm{NO}_{3}-\mathrm{N}$ & -0.04 & $0.37 *$ & $-0.41 *$ & $0.36 * *$ & $0.49 *$ & -0.06 & 0.02 & 1.01 \\
\hline $\mathrm{NH}_{4}-\mathrm{N}$ & $-\mathbf{0 . 3 7} *$ & $-0.43 *$ & $0.31 * *$ & $-0.41 *$ & $-0.55 *$ & -0.01 & -0.20 & $0.88 * *$ \\
\hline DON & $-\mathbf{0 . 5 2} *$ & $-0.45 *$ & $0.43 *$ & -0.19 & $-0.44 *$ & -0.02 & -0.04 & $0.50 *$ \\
\hline $\mathrm{SO}_{4}-\mathrm{S}$ & $-\mathbf{0 . 5 7} *$ & $-0.54 *$ & $0.62 *$ & $-0.43 *$ & $-0.6 *$ & 0.10 & -0.03 & $0.87 *$ \\
\hline $\mathrm{PO}_{4}-\mathrm{P}$ & -0.04 & 0.24 & $-\mathbf{0 . 3 8} *$ & $0.45 *$ & $0.40 *$ & $0.34 *$ & -0.14 & $1.06 *$ \\
\hline DOC & $-0.51 *$ & $-\mathbf{0 . 5 7} *$ & $0.66 *$ & $-0.51 *$ & $-0.71 *$ & -0.11 & 0.01 & $0.80 *$ \\
\hline Escherichia coli ${ }^{\mathrm{d}}$ & -0.09 & 0.09 & 0.44 & -0.04 & -0.24 & 0.38 & 0.31 & n.a. \\
\hline $\mathrm{Ca}$ & -0.09 & $-0.49 *$ & $0.56 *$ & -0.26 & $-0.35 *$ & 0.12 & -0.1 & 0.97 \\
\hline $\mathrm{K}$ & -0.25 & $-0.48 *$ & $0.71 *$ & -0.33 & $-0.68 *$ & -0.12 & -0.03 & 0.96 \\
\hline $\mathrm{Mg}$ & $-0.43 *$ & $-0.55 *$ & $0.66 *$ & $-0.45 *$ & $-0.66 *$ & -0.06 & -0.13 & 0.95 \\
\hline $\mathrm{Na}$ & -0.28 & $-0.48 *$ & $0.64 *$ & -0.27 & $-0.37 *$ & 0.26 & -0.13 & 0.93 \\
\hline As & -0.16 & $-0.52 *$ & $0.64 *$ & -0.23 & $-0.45 *$ & 0.01 & 0.02 & $0.96 *$ \\
\hline $\mathrm{Al}$ & -0.04 & -0.24 & $0.41 *$ & -0.25 & $-0.41 *$ & -0.22 & 0.02 & 0.98 \\
\hline $\mathrm{Cd}$ & $-0.29 * *$ & $-\mathbf{0 . 4 3} *$ & $0.47 *$ & $-0.35 * *$ & $-0.44 *$ & 0.22 & $-0.35 *$ & 0.93 \\
\hline $\mathrm{Co}$ & $-0.48 *$ & $-0.52 *$ & $0.46 *$ & $-0.40 *$ & $-0.69 *$ & -0.05 & -0.19 & $0.87 *$ \\
\hline $\mathrm{Cu}$ & $-0.57 *$ & $-0.58 *$ & $0.70 *$ & $-0.35 * *$ & $-0.6 *$ & 0.15 & -0.12 & 0.88* \\
\hline $\mathrm{Fe}$ & -0.25 & $-0.35 *$ & $0.41 *$ & $-0.45 *$ & $-\mathbf{0 . 6 7} *$ & -0.20 & 0.07 & 0.99 \\
\hline $\mathrm{Hg}$ & $-0.64 *$ & $-0.56 *$ & $0.63 *$ & $-0.84 *$ & $-0.70 *$ & 0.11 & -0.16 & 0.90 \\
\hline $\mathrm{Mn}$ & $-0.49 *$ & $-0.49 *$ & $0.53 *$ & $-0.53 *$ & $-0.68 *$ & -0.25 & -0.03 & 0.95 \\
\hline $\mathrm{Ni}$ & 0.03 & $-0.34 *$ & $0.53 *$ & -0.11 & -0.24 & 0.06 & -0.19 & 0.93 \\
\hline $\mathrm{Pb}$ & 0.27 & 0.01 & $0.33 *$ & 0.01 & 0.05 & 0.03 & -0.27 & 0.97 \\
\hline $\mathrm{V}$ & $-0.41 *$ & $-0.61 *$ & $0.73 *$ & $-0.40 *$ & $-0.65 *$ & 0.12 & -0.18 & 0.93* \\
\hline $\mathrm{Zn}$ & $-0.46 *$ & $-0.46 *$ & $0.65 *$ & -0.28 & $-0.45 *$ & 0.27 & -0.27 & $0.81 *$ \\
\hline
\end{tabular}

Only rainfall variables that yielded significant solute regressions are shown. Correlations with a significance level less than 0.1 are in bold.

${ }^{a} n=35$ for all solutes except for $E$. coli, where $n=9$, and $\mathrm{Hg}$, where $n=13$.

${ }^{\mathrm{b}} n=31$ for all solutes except for $E$. coli, where $n=9$, and $\mathrm{Hg}$, where $n=13$.

${ }^{c} n=26$ for all solutes except for $E$. coli, where $n=6$ and $\mathrm{Hg}$, where $n=9$.

d Because E. coli was only measured for two to three storm events for each site, we have not calculated NCL.

* Solute correlations and $m_{\mathrm{NCL}-\mathrm{NCQ}}$ with $p<0.05$.

$* *$ Solute correlations and $m_{\mathrm{NCL}-\mathrm{NCQ}}$ with $0.05<p<0.1$. 
a)

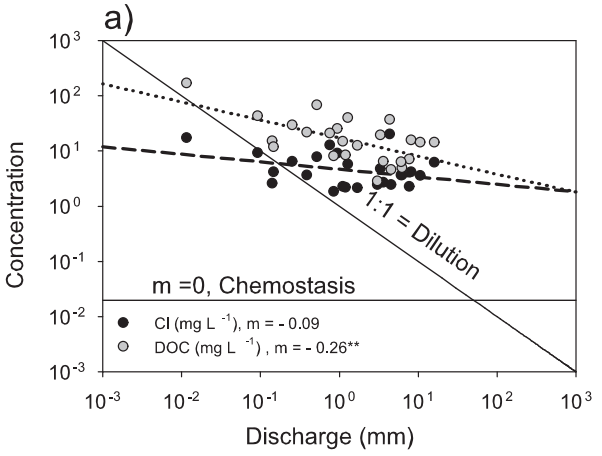

c)

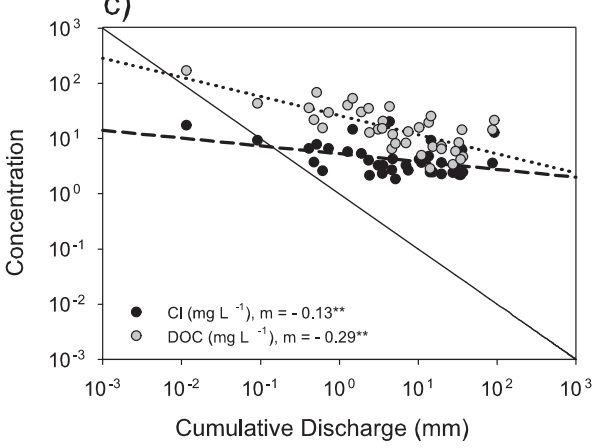

b)

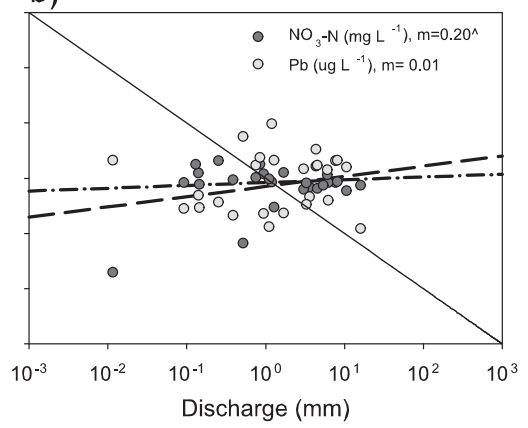

d)

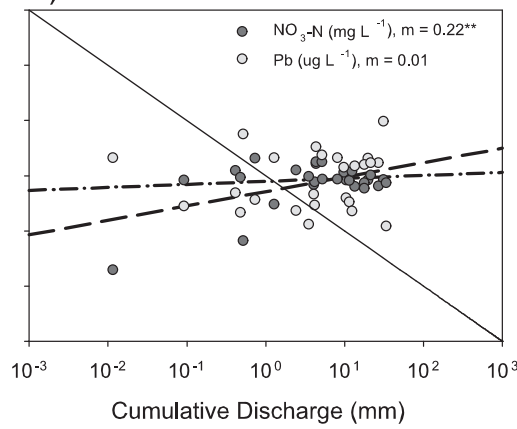

** denotes significant regressions at $p<0.05$.

$\wedge$ denotes regression at $0.05 ? \mathrm{p}<0.10$.

Figure 5. Mean event concentrations of $\mathrm{Cl}, \mathrm{DOC}, \mathrm{NO}_{3}-\mathrm{N}$ and $\mathrm{Pb}$ against (a and b) discharge and (c and d) cumulative discharge. Data that plot along a 0 slope line denote solute chemostasis, whereas points plotting along a $-1: 1$ line exhibit solute dilution

a)

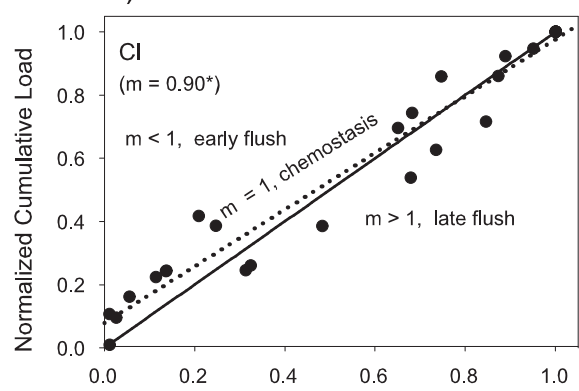

c)

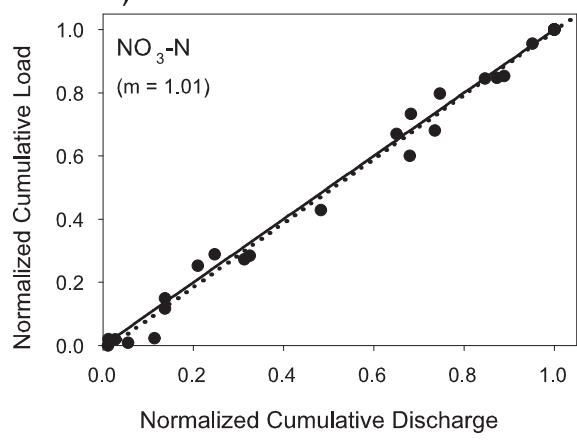

b)

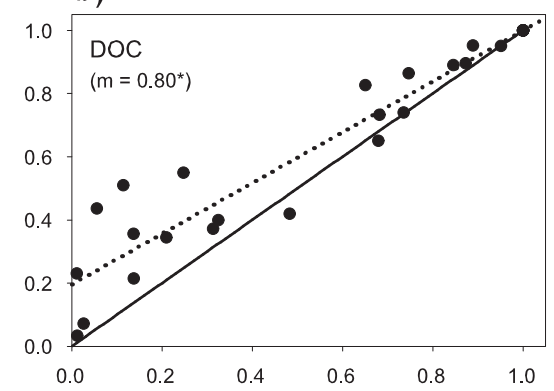

d)

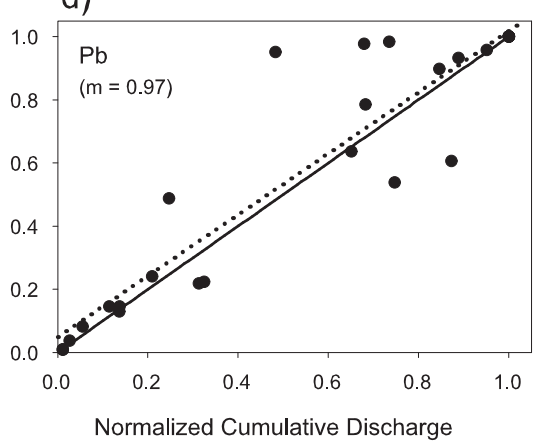

* denotes slopes significantly different from 1.

Figure 6. NCL versus NCQ for $\mathrm{Cl}$, DOC, $\mathrm{NO}_{3}-\mathrm{N}$ and $\mathrm{Pb}$. Solid lines denote slope $(m)=1$; dotted lines are regressions for NCL-NCQ. Slopes $(m)<1$ denote early seasonal solute flushing, $m>1$ indicate late season flush and $m=1$ indicate seasonal solute chemostasis

correlated with $P_{\text {depth }}(\bar{r}=-0.51)$. Clusters $\mathrm{C} 1$ and $\mathrm{C} 2$ were significantly and negatively correlated with $P_{\text {duration }}$ ( -0.56 and -0.46 , respectively). Clusters C1, C2 and C3 were positively correlated with time since antecedent rainfall, with $\mathrm{C} 1$ having the strongest significant positive correlation $(\bar{r}=0.62,0.53$ and 0.53 for $\mathrm{C} 1, \mathrm{C} 2$ and $\mathrm{C} 3$, respectively), whereas $\mathrm{C} 5$ exhibited a significant negative correlation to time since antecedent rainfall $(-0.39)$. Only 


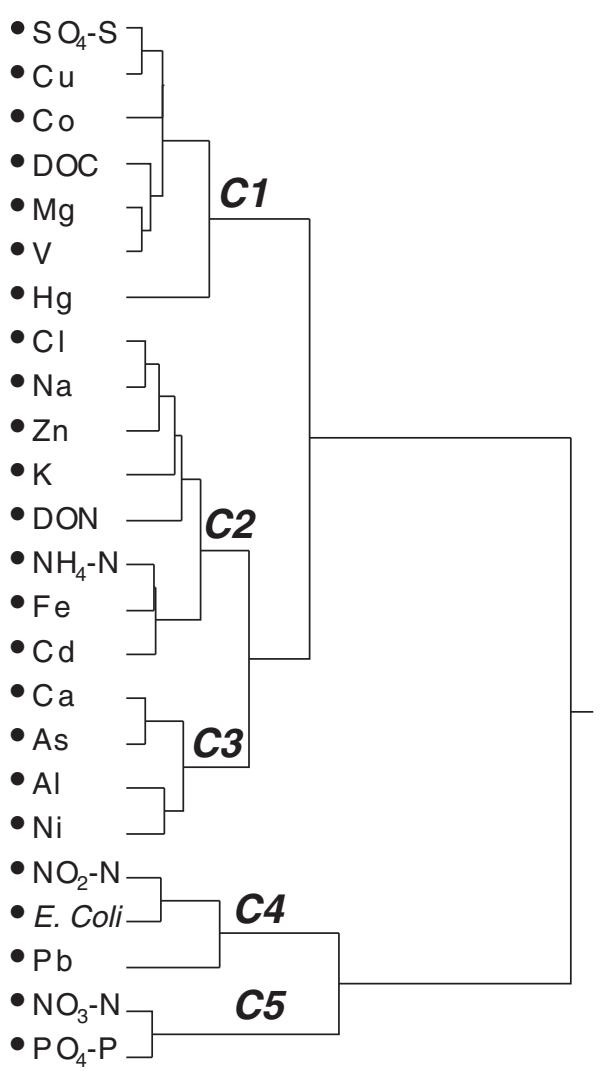

Figure 7. Clustering analysis dendrogram The clusters are indicative of 5 major patterns of seasonal solute responses

clusters C1 and C5 were significantly correlated with discharge; $\mathrm{C} 1$ was negatively correlated $(-0.48)$, whereas C5 was positively correlated (0.41). A similar pattern was observed for cumulative discharge where $\mathrm{C} 1$ had a stronger significant negative correlation $(-0.67)$ than $\mathrm{C} 2$ $(-0.51)$ and $\mathrm{C} 5$ had a significant positive correlation (0.47). Curiously, C4 was not significantly or strongly correlated to any of the aforementioned variables, although the strongest correlation was with time since antecedent rainfall.

\section{DISCUSSION}

\section{Hydrology}

Although a larger number of rainfall events led to greater cumulative seasonal rainfall for the 2008 monsoon, the consistency of rainfall characteristics across sites and years suggests that the differences observed in discharge and runoff ratios across catchments arise because of differences in rainfall partitioning at each site. Across sites, the runoff ratios that we report in this study agree with runoff ratios reported for other arid and semiarid urban catchments (Ishaq and Alassar, 1999; Goldshleger et al., 2009) and are consistent with other studies where the smallest and largest discharge and runoff ratios occur at the lowest and highest imperviousness (Arnold and Gibbons, 1996; Rose and Peters, 2001; Lerner, 2002; Burns et al., 2005; Endreny, 2005; Shuster et al., 2005; Glick, 2009). The runoff ratios that we report are larger than those in nonurbanized catchments in the semiarid Walnut Gulch Experimental Watershed (e.g. mean runoff ratios of 2.4, 4.6 and $5.5 \%$ at watersheds 11 , 112 , and 4, respectively; http://www.tucson.ars.ag.gov/ dap/; Goodrich et al., 2008), providing further evidence that urbanization increases runoff quantity in small semiarid catchments and suggesting that urbanization alters the localized water balance by reducing catchment water storage and enhancing runoff generation.

Hydrologic responses at the more impervious sites, $\mathrm{MD}, \mathrm{MX}$ and CM, appear to be mainly controlled by the depth of each individual rainfall event and not by the temporal distribution of rainfall. The larger imperviousness and therefore smaller soil footprint at these sites may explain the lack of correlation of discharge and runoff ratio to antecedent conditions, cumulative rainfall and time since antecedent rainfall, which point to the absence of seasonal catchment wetting. It is plausible that by reducing pervious surfaces, imperviousness diminishes a catchment's capacity for soil-water storage, which when combined with the high daily evapotranspirative demand typical of arid and semiarid regions (Howell et al., 1983; Grimmond and Oke, 1999), may decrease or eliminate the effect that antecedent conditions could affect rainfallrunoff responses.

In contrast, antecedent conditions explain a significant fraction of the variance in discharge and runoff ratio at LD (Table II), which is the least impervious (21\%) site, suggesting that the degree of catchment wetting before a rainfall event is a more important control of hydrologic responses at low imperviousness than $P_{\text {depth }}$ and $P_{\text {intensity. }}$ Several studies clearly demonstrate that antecedent conditions significantly affect rainfall-runoff processes in nonurbanized semiarid catchments (Osborn and Lane, 1969; Loik et al., 2004); however, similar results have been reported in only a handful of urban studies and laboratory experiments (e. g. Shuster et al., 2008; Smith et al., 2005). It is plausible that a larger fraction of rainfall is partitioned into soil infiltration and ephemeral channel storage at this low imperviousness site, thus reducing the soil-water storage capacity and increasing the proportion of rainfall partitioned into runoff during subsequent precipitation events.

Our analyses indicate that independently, $P_{\text {depth, }}$, imperviousness and all other rainfall variables are poor predictors of hydrologic responses. However, our twocomponent statistical model indicates that combined, $P_{\text {depth }}$ and imperviousness impart a significant effect on discharge and runoff ratios (Figure 3; Equations 7 and 8). Specifically, our model suggests that the hydrologic responses resulting from any given rainfall input largely depend on the degree of imperviousness.

Although our study was not designed to test the effect of catchment size on hydrologic responses, our data indicate that discharge and runoff ratios decrease with increasing catchment size, which is consistent with observations made in other semiarid sites (Boughton and Stone, 1985; Stone et al., 2008). Surprisingly, models 


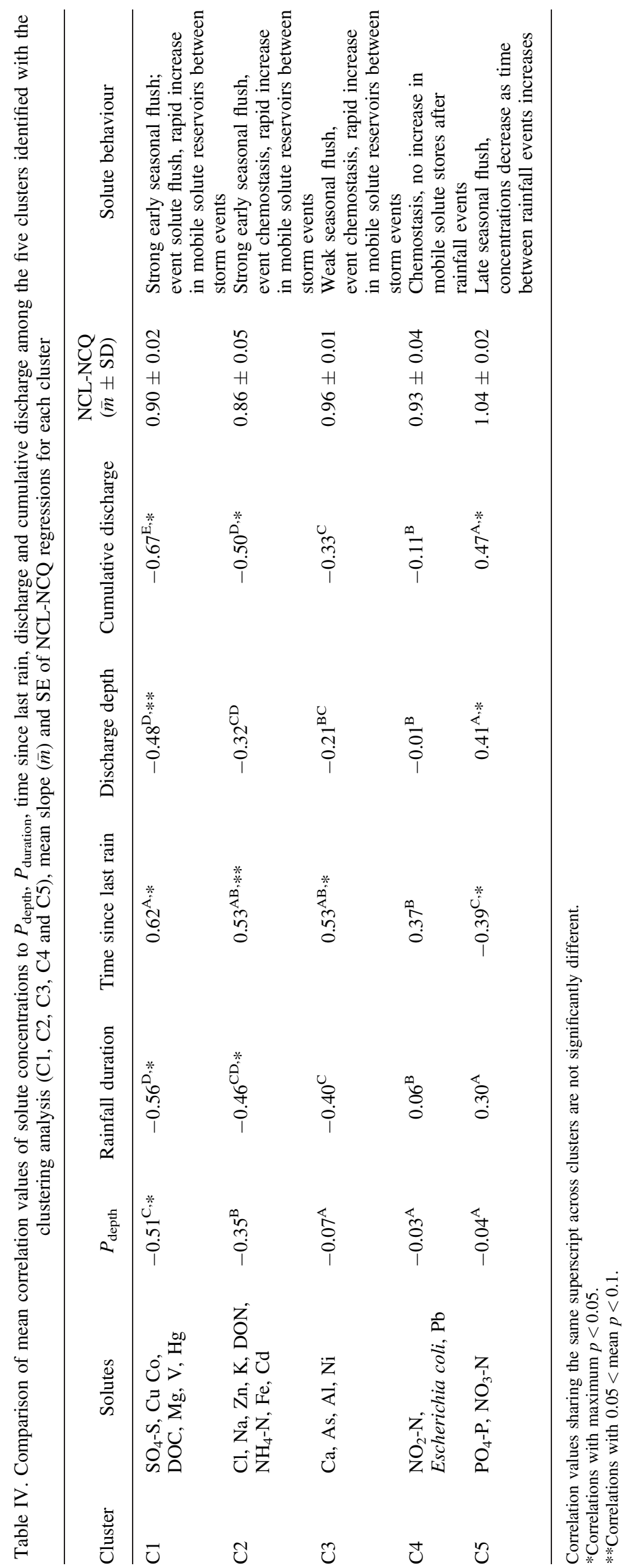


in our study including catchment size and $P_{\text {depth }}$ did not yield significant statistical predictions of discharge and runoff ratio. We hypothesize that shifts in rainfall partitioning post-urbanization as well as the high spatial variability of summertime convective rainfall may obscure the effect of catchment size on discharge magnitude and timing. In summary, we show that urbanization alters rainfall partitioning in semiarid catchments resulting in decreased seasonal catchment wetting and enhanced delivery of event runoff to ephemeral waterways, suggesting that by delivering more runoff to areas of focused recharge, urbanization may enhance renewable groundwater supplies.

\section{Water quality}

In contrast with a large body of literature documenting urban runoff quality across a range of climates, we found that the overall quality of urban runoff does not vary in response to catchment size or imperviousness (Table III, e.g. Brabec et al., 2002; Glick, 2009; Schueler et al., 2009; Walsh et al., 2005; Wenger et al., 2009), suggesting that variable solute sourcing and pervious areas play an important role in solute transport during storm events and retention between storm events. Consistent with a large number of urban (e.g. Lee et al., 2002; Westerlund et al., 2003; Asaf et al., 2004; Soller et al., 2005) and nonurban studies (e.g. Kirchner et al., 2000; Welter et al., 2005; Godsey et al., 2009), we observed variable solute responses to rainfall and discharge (Figures 4 and 5; Table III). Specifically, several solutes exhibited event and seasonal solute dilution, whereas other solutes did not vary with discharge and cumulative discharge, indicating event and seasonal chemostasis. The NCL-NCQ regressions for half of the solutes addressed in this study are indicative of early seasonal solute flushing (Figure 6 and Table IV), which are consistent with observations made by Asaf et al. (2004) and Lee et al. (2004) and which are clearly highlighted by the exponential decay of $\mathrm{Cl}$ and DOC (Figure 4), among others, over time.

Most striking is that most solute concentrations, with the exception of $\mathrm{NO}_{3}-\mathrm{N}$ and $\mathrm{PO}_{4}-\mathrm{P}$, varied positively with time since antecedent rainfall, suggesting that mobile solute reservoirs increase with increasing time between rainfall events. Our results are consistent with the 'pollutant washoff' concept and with literature where solute loads are, in part, reported to be a function of the length of time between rainfall events (e.g. Barbe $e t$ al., 1996; Lee et al., 2004; Soller et al., 2005; Maestre and Pitt, 2006; Lewis and Grimm, 2007; Soonthornnonda et al., 2008; Avellaneda et al., 2009). It is important to note that an increase in the magnitude of solute reservoirs does not exclusively refer to solute store replenishment via wet and aeolian deposition. Mechanisms that may increase the magnitude of easily mobilized solute reservoirs include physical and chemical weathering of geologic and urban materials (Norra et al., 2008), photo degradation of organic matter (Austin and Ballare, 2010), nonpoint solute sourcing (Lohse et al., 2008), variable contributing areas and solute transport (Bencala, 1984; Harms and Grimm, 2010) and processes such as decomposition and mineralization of organic matter in soils (Schlesinger, 1997) of pervious areas and within stream channels. Overall, our study supports the findings of Lee $e t$ al. (2004), who show that antecedent dry days have a larger effect on solute concentrations than rainfall characteristics.

The high variability of solute responses to rainfall and runoff presents a challenge in identifying the factors that control urban runoff quality. However, with the clustering analysis, we identified five solute response patterns that point to distinct solute sourcing and mobilization mechanisms (Table IV). Clusters C1 and C2 exhibit similar solute response patterns. The negative correlation of $\mathrm{C} 1$ solutes to $P_{\text {duration }}$ and discharge, and the significant positive correlation to time since antecedent rainfall suggests that these solutes are readily flushed during runoff events and that solute reservoirs rapidly increase in magnitude between runoff events. The significant negative correlation of $\mathrm{C} 1$ and $\mathrm{C} 2$ to cumulative discharge and the NCL-NQL slopes point to an early seasonal solute flush and to potential solute retention and cycling later in the season of biogeochemically active solutes like $\mathrm{DOC}, \mathrm{SO}_{4}-\mathrm{S}, \mathrm{DON}$ and $\mathrm{NH}_{4}-\mathrm{N}$. The major difference in the response between $\mathrm{C} 1$ and $\mathrm{C} 2$ responses is that $\mathrm{C} 1$ solutes appear to be more readily mobilized than $\mathrm{C} 2$ solutes as indicated by the stronger negative $P_{\text {depth }}$, discharge and cumulative discharge correlations. Interestingly, priority pollutants such as $\mathrm{Zn}, \mathrm{Co}, \mathrm{Cd}$ and $\mathrm{Hg}$ (Athayde et al., 1983) and biogeochemically active solutes DOC, $\mathrm{SO}_{4}-\mathrm{S}, \mathrm{DON}$ and $\mathrm{NH}_{4}-\mathrm{N}$ clustered with $\mathrm{C} 1$ and $\mathrm{C} 2$, suggesting that in semiarid catchments, major factors controlling urban runoff quality are solute mobilization and potential retention and biogeochemical cycling as wetting event magnitude and duration increases.

Concentrations of $\mathrm{C} 3$ solutes, in contrast, do not vary significantly with $P_{\text {depth }}$ or discharge, although mobile solute reservoirs appear to increase rapidly in magnitude between rainfall events and do exhibit a very weak early season solute flush. These complex responses may arise from variable solute sourcing and mobilization. Cluster C3 solutes, specifically $\mathrm{Ca}$ and $\mathrm{Ni}$, are geologically abundant in the Tucson Basin (Robertson, 1989; Tadayon, 1995a; Tadayon, 1995b). It is plausible that early season mobilization of large solute stores accumulated over the dry months preceding the summer monsoon, coupled with widespread solute sourcing throughout the monsoon and weathering of geologic materials during and between rainfall events, results in solute chemostasis with respect to discharge and an overall weak seasonal flushing response.

Cluster $\mathrm{C} 4$ exhibits the strongest solute chemostasis, indicating that solute mobilization is invariant over time. Solute chemostasis may arise from variable solute sourcing and transport among our sites. For example, we expect $E$. coli stores to increase at different rates among our sites between rainfall events because known $E$. coli sources (e.g. wildlife, agricultural livestock and pets) are 
related to land use. The variability of solute sourcing across sites results in a chemostatic response pattern. Therefore, we suggest that the seasonal dynamics of $\mathrm{C} 4$ solutes are more tightly linked to the spatial characteristics of land cover than to the temporal characteristics of rainfall and runoff (Gallo et al., in revision).

Finally, cluster C5 is the only cluster that exhibits a significant positive response to discharge and cumulative discharge, a late season flush and decreasing solute concentrations with increasing time since antecedent rainfall. Phosphorous $(\mathrm{P})$ mobility in desert soils with abundant carbonates is driven by the preferential sorption of $\mathrm{P}$ to $\mathrm{Ca}$ and subsequent precipitation of $\mathrm{Ca}-\mathrm{P}$ complexes (Lajtha and Schlesinger, 1988; GonzalezPradas et al., 1993; Cross and Schlesinger, 2001; Carreira et al., 2006). Laboratory experiments show that a fraction of labile sorbed phosphorous can be released with salt and acidic solutions (Cross and Schlesinger, 2001; Carreira et al., 2006) within hours of soil treatment (Shariatmadari et al., 2006; Biabanaki and Hosseinpur, 2009). The rapid desorption and mobilization of phosphorous observed in laboratory experiments suggests that the $\mathrm{PO}_{4}-\mathrm{P}$ we observed in runoff could be mobilized after soil wetting and may vary with the extent of wetting, resulting in increasing concentrations with increasing discharge and cumulative discharge. Interestingly, $\mathrm{PO}_{4}-\mathrm{P}$ was the only solute to exhibit a significant positive correlation with imperviousness. Although a type I error could explain this relationship, it is plausible that in addition to sourcing form $\mathrm{Ca}-\mathrm{P}$ complex dissolution, elevated $\mathrm{PO}_{4}-\mathrm{P}$ deposition, as has been shown in the urban core of Phoenix, Arizona (Lohse et al., 2008), in the months preceding the monsoon and enhanced mobility from impervious areas result in a positive correlation of solute concentrations with imperviousness.

With regard to $\mathrm{NO}_{3}-\mathrm{N}$, water limitations and the quick resetting of moisture conditions in the interstorm period (Table II) may limit biogeochemical processes such as nitrogen mineralization and fixation and subsequent $\mathrm{NO}_{3}-\mathrm{N}$ production in soils. Physical sorption and precipitation of $\mathrm{PO}_{4}-\mathrm{P}$ in soil solution and biological uptake of $\mathrm{PO}_{4}-\mathrm{P}$ and $\mathrm{NO}_{3}-\mathrm{N}$ are additional mechanisms that may decrease solute stores as time since antecedent rainfall increases. Although decreasing $\mathrm{PO}_{4}-\mathrm{P}$ with increasing time since antecedent rainfall is reported in at least one other study (Passeport and Hunt, 2009), the arid land literature reports increasing rather than decreasing $\mathrm{NO}_{3}-\mathrm{N}$ as time since antecedent rainfall increases because of elevated nitrification after a rainfall pulse and as flow path length increases (Welter et al., 2005). It is plausible that the changes in flow paths and the quickly resetting moisture conditions alter physical and biogeochemical processes that control nitrogen, phosphorous and carbon fluxes and transformations in urban catchments. Further work is needed to assess how urbanization alters biogeochemical processes and nutrient cycling pathways given that the soil properties, the magnitude and frequency of wetting, the type of urban landscape and the length and characteristics of flow paths significantly affect nitrogen dynamics in semiarid regions (Loik et al., 2004; Welter et al., 2005; Hall et al., 2009; McIntyre et al., 2009).

\section{CONCLUSIONS}

The variability of hydrologic responses across the study sites was best explained by the combined effect of rainfall depth with imperviousness, indicating that the effect of rainfall on runoff responses varies with the extent of imperviousness. With the exception of the low imperviousness catchment, we found no evidence of seasonal catchment wetting resulting in increased water yields across our sites. Combined with increases in discharge and runoff ratio as imperviousness increases, our study suggests that urbanization enhances rainfall partitioning to runoff, decreases the potential for catchment water storage and enhances the resetting of moisture conditions between rainfall events. Solute concentrations in runoff did not vary with catchment size or imperviousness, and most mobile solute reservoirs increased with increasing time since antecedent rainfall. Using clustering analyses, we identified five general seasonal solute responses: (i) strong event and seasonal solute flush, (ii) event chemostasis and strong seasonal solute flush, (iii) event chemostasis and weak seasonal flush, (iv) event and seasonal chemostasis and (v) late seasonal flush.

Together, our results show that urbanization enhances the fraction of rainfall delivered to the major ephemeral waterways of the region, which, through focused recharge, may be beneficial for sustaining local water resources. However, rapid resetting of moisture conditions, particularly at higher imperviousness, may limit biogeochemical processing of solutes between wetting pulses, which combined with rapid buildup of solute reservoirs between rainfall events, enhances solute transport during runoff, pointing to a direct trade-off between the quantity of runoff available for recharge and its effect on groundwater supplies. Further research is needed to assess the extent to which urban runoff in semiarid regions alters biogeochemical processing between rainfall events and subsequent solute sourcing, transport and groundwater quality. However, we show that hydrologic responses of semiarid catchments are controlled by imperviousness and event scale hydrologic partitioning, whereas wetting magnitude, frequency and timing alter solute stores readily available for transport and control seasonal hydrochemical responses. We suggest that stormwater monitoring should be designed to capture a range of rainfall depths and antecedent dry days throughout the season to appropriately assess the effect of best management practices on stormwater quality.

\section{ACKNOWLEDGMENTS}

This study was supported by the Arizona's Technology and Research Initiative Fund (TRIF), the USDA-ARS Water Management and Conservation National Program No. 211, the Sustainability of Semi-Arid Hydrology and Riparian 
Areas (SAHRA) program, the National Science Foundation grant nos. DEB 0918373 and 1063362 and by the following graduate fellowship support: the USDA Ecohydrology Fellowship, the University of Arizona's Graduate College Diversity Fellowship and the University of Arizona's Water Sustainability Graduate Study Fellowship. Dr Kathleen Lohse, now at Idaho State University, was supported by the National Science Foundation award no. EPS-0814387. The authors thank Dr Jennifer McIntosh, Dr Thomas Meixner and Dr David Goodrich for their technical support; Dr Craig Rasmussen for his friendly manuscript review; Margaret Snyder, Navid Dejwakh, Shane Clark, Mark Carlson, Daniel Wisheropp and Claressa Martinez for their help in collecting and processing runoff samples; and the Rainlog. org citizen scientists for their invaluable contribution of rainfall data.

\section{REFERENCES}

Arnold CL, Gibbons CJ. 1996. Impervious surface coverage-The emergence of a key environmental indicator. Journal of the American Planning Association 62: 243-258. DOI: 10.1080/01944369608975688

Asaf L, Nativ R, Shain D, Hassan M, Geyer S. 2004. Controls on the chemical and isotopic compositions of urban stormwater in a semiarid zone. Journal of Hydrology 294: 270-293. DOI: 10.1016/j.jhydrol. 2004.02.010.

ASCE. 1996. Hydrology Handbook. Manuals and Reports on Engineering Practice. American Society of Civil Engineers: New York; 784.

Athayde DA, Shelley PE, Dricoll ED, Gaboury D, Boyd GB. 1983. Results of the Nationwide Urban Runoff Program. Water Planning Division, U.S. Environmental Protection Agency: U.S. G.P.O., WH-554: 195: Washington, D.C.

Austin AT, Ballare CL. 2010. Dual role of lignin in plant litter decomposition in terrestrial ecosystems. Proceedings of the National Academy of Sciences 107: 4618-4622. DOI: 10.1073/pnas.0909396107

Avellaneda P, Ballestero TP, Roseen RM, Houle JJ. 2009. On Parameter Estimation of Urban Storm-Water Runoff Model. Journal of Environmental Engineering-Asce 135: 595-608. DOI: 10.1061/(ASCE) EE.1943-7870.0000028

Barbe DE, Cruise JF, Mo X. 1996. Modeling the buildup and washoff of pollutants on urban watersheds. Water Resources Bulletin 32: 511-519. DOI: 10.1111/j.1752-1688.1996.tb04049.x

Bencala KE. 1984. Interactions of Solutes and Streambed Sediment: 2. A Dynamic Analysis of Coupled Hydrologic and Chemical Processes That Determine Solute Transport. Water Resources Research 20: 1804-1814. DOI: 10.1029/WR020i012p01804

Berling-Wolff S, Wu J. 2004. Modeling urban landscape dynamics: A case study in Phoenix, USA. Urban Ecosystems 7: 215-240. DOI: 10.1023/B:UECO.0000044037.23965.45

Biabanaki FS, Hosseinpur AR. 2009. Phosphorus release rate and plant response in some calcareous soils. Archives of Agronomy and Soil Science 55: 91-103. DOI: 10.1080/03650340802350618

Blasch KW, Ferre TPA, Hoffmann JP, Fleming JB. 2006. Relative contributions of transient and steady state infiltration during ephemeral streamflow. Water Resources Research 42: W08405. DOI: 10.1029/ 2005WR004049

Boughton WC, Stone JJ. 1985. Variation of Runoff with Watershed Area in a Semi-Arid Location. Journal of Arid Environments 9: 13-25.

Brabec E, Schulte S, Richards PL. 2002. Impervious Surfaces and Water Quality: A Review of Current Literature and Its Implications for Watershed Planning. Journal of Planning Literature 16: 499-514. DOI: $10.1177 / 088541202400903563$

Brooks PD, Haas PA, Huth AK. 2007. Seasonal variability in the concentration and flux of organic matter and inorganic nitrogen in a semiarid catchment, San Pedro River, Arizona. Journal of Geophysical Research-Biogeosciences 112: G03S04. DOI: 10.1029/2006JG000275

Burns D, Vitvar T, McDonnell J, Hassett J, Duncan J, Kendall C. 2005. Effects of suburban development on runoff generation in the Croton River basin, New York, USA. Journal of Hydrology 311: 266-281. DOI: 10.1016/j.jhydrol.2005.01.022

Carlson MA, Lohse KA, McIntosh JC, McLain JET. 2011. Impacts of Urbanization on Groundwater Quality and Recharge in a Semi-arid
Alluvial Basin. Journal of Hydrology 409: 196-211. DOI: 10.1016/ j.jhydrol.2011.08.020

Carreira JA, Vinegla B, Lajtha K. 2006. Secondary $\mathrm{CaCO} 3$ and precipitation of $\mathrm{P}-\mathrm{Ca}$ compounds control the retention of soil $\mathrm{P}$ in arid ecosystems. Journal of Arid Environments 64: 460-473. DOI: 10.1016/ j.jaridenv.2005.06.003

Chralowicz D, Dominguez A, Goff T, Mascali M, Taylor E. 2001. Infiltration of urban stormwater runoff to recharge groundwater used for drinking water: a study of the San Fernando Valley, California. University of California, Donald Bren School of Environmental Science and Management: Santa Barbara; 104.

Ciach GJ. 2003. Local Random Errors in Tipping-Bucket Rain Gauge Measurements. Journal of Atmospheric and Oceanic Technology 20: 752-759. DOI: 10.1175/1520-0426(2003)20<752:LREITB > 2.0.CO;2

Coes AL, Pool DR. 2007. Ephemeral-stream channel and basin-floor infiltration and recharge in the Sierra Vista subwatershed of the upper San Pedro basin, southeastern Arizona. In Ground-water recharge in the arid and semiarid southwestern United States. Stonestrom, DA, Constantz J, Ferre TPA, Leake SA (eds). Unites States Geological Survey. Ground-water Resources, Program: Reston, Va; 253-311 http:// pubs.usgs.gov/pp/pp1703/j/

Comrie AC, Broyles B. 2002. Variability and spatial modeling of finescale precipitation data for the Sonoran Desert of south-west Arizona. Journal of Arid Environments 50: 573-592.

Cross AF, Schlesinger WH. 2001. Biological and geochemical controls on phosphorus fractions in semiarid soils. Biogeochemistry 52: 155-172.

City of Santa Clara, Water Utility. 2011. 2010 Urban Water Management Plan. Santa Clara, CA. Retrieved from: http://santaclaraca.gov/ Modules/ShowDocument.aspx?documentid=5314

Decook KJ, Foster KE. 1984. Systems for Rainfall and Runoff Use, Tucson, Arizona. Water Resources Bulletin 20: 883-888.

Deletic A. 1998. The first flush load of urban surface runoff. Water Research 32: 2462-2470.

Driver NE, Troutman BM. 1989. Regression models for estimating urban storm-runoff quality and quantity in the United States. Journal of Hydrology 109: 221-236.

Eastoe CJ, Gu A, Long A. 2004. The origins, ages and flow paths of gorundwater in Tucson Basin: results of a study of multiple isotope systems. In Groundwater recharge in a desert environment: the southwestern United States, Hogan JF, Phillips FM, Scanlon BR (eds). American Geophysical Union: Washington, DC.

Edwards AMC. 1973. The variation of dissolved constituents with discharge in some Norfolk rivers. Journal of Hydrology 18: 219-242.

Endreny TA. 2005. 117: Land Use and Land Cover Effects on Runoff Processes: Urban and Suburban Development. In Encyclopedia of hydrological sciences, Part 10. Rainfall-Runoff Processes, Anderson, MG, McDonnell JJ (eds). http://onlinelibrary.wiley.com/doi/10.1002/ 0470848944.hsa122/abstract

Fischer D, Charles EG, Baehr AL. 2003. Effects of stormwater infiltration on quality of groundwater beneath retention and detention basins. Journal of Environmental Engineering-Asce 129: 464-471.

Gallo EL, Brooks P, Lohse KA, McLain JE. In revision. Land cover controls on discharge and runoff solution chemistry of semi-arid urban catchments in the Southwest. Journal of Hydrology. In revision.

Garcia M, Peters-Lidard CD, Goodrich DC. 2008. Spatial interpolation of precipitation in a dense gauge network for monsoon storm events in the southwestern United States. Water Resources Research 44: 14.

Gelt J, Henderson J, Seasholes K, Tellman B, Woodard G, Carpenter K, Hudson C, Sherif S. 1999. Water in the Tucson area: seeking sustainability, a status report. The University of Arizona: Tucson, AZ.

Glick RH. 2009. Impacts of Impervious Cover and Other Factors on StormWater Quality in Austin, Tex. Journal of Hydrologic Engineering 14: 316-323.

Godsey SE, Kirchner JW, David WC. 2009. Concentration-discharge relationships reflect chemostatic characteristics of US catchments. Hydrological Processes 23: 1844-1864.

Goldshleger N, Shoshany M, Karnibad L, Arbel S, Getker M. 2009. Generalising relationships between runoff-rainfall coefficients and impervious areas: an integration of data from case studies in Israel with data sets from Australia and the USA. Urban Water Journal 6: 201-208.

Gonzalez-Pradas E, Villafranca-Sanchez M, Socias-Viciana M. 1993. Phosphate and Nitrate Sorption on Calcareous Soils from Spain. Arid Soil Research and Rehabilitation 7: 181-190. DOI: 10.1080/ 15324989309381347

Goodrich DC, Williams DG, Unkrich CL, Hogan JF, Scott RL, Hultine K, Pool D, Coes AL, Miller S. 2004. Comparison of methods to estimate Ephemeral Channel Recharge, Walnut Gulch, San Pedro River Basin, 
Arizona. In Groundwater recharge in a desert environment: the southwestern United States, Hogan, JF, Phillips FM, Scanlon BR (eds). American Geophysical Union: Washington, DC.

Goodrich DC, Unkrich CL, Keefer TO, Nichols MH, Stone JJ, Levick LR, Scott RL. 2008. Event to multidecadal persistence in rainfall and runoff in southeast Arizona. Water Resources Research 44: W05S14. DOI: 10.1029/2007WR006222

Grimmond CSB, Oke TR. 1999. 5-SURFACE WATER: Hydrology and meteorology inputs-Evapotranspiration rates in urban areas. IAHS Publication 259: 235.

Guido Z. 2008. Understanding the Southwestern Monsoon. Southwest Climate Change Network. Retrieved from the University of Arizona's Southwest Climate Change Network Web site: http://www. southwestclimatechange.org/feature-articles/southwest-monsoon

Hall SJ, Ahmed B, Ortiz P, Davies R, Sponseller RA, Grimm NB. 2009. Urbanization Alters Soil Microbial Functioning in the Sonoran Desert. Ecosystems 12: 654-671.

Harms TK, Grimm NB. 2010. Influence of the hydrologic regime on resource availability in a semi-arid stream-riparian corridor. Ecohydrology 3: 349-359. DOI: 10.1002/eco.119

Heaney JP, Huber WC. 1984. Nationwide Assessment of Urban Runoff Impact on Receiving Water-Quality. Water Resources Bulletin 20: 35-42.

Hoffmann JP, Blasch KW, Pool DR, Bailey MA, Callegary JB. 2007. Estimated infiltration, percolation, and recharge rates at the Rillito Creek focused recharge investigation site, Pima County, Arizona. In Professional Paper 1703 - Ground-Water Recharge in the Arid and Semiarid Southwestern United States. Stonestrom DA, Ferre TPA, and Leake SA (eds). Geological Survey and U.S. Department of the Interior; [Reston, Va.]: 185-220. Retrieved from: http://pubs.usgs.gov/pp/pp1703/h/

Howell TA, Phene CJ, Meek DW, Miller RJ. 1983. Evaporation from screened class a pans in a semi-arid climate. Agricultural Meteorology 29: $111-124$.

Ishaq AM, Alassar RS. 1999. Characterizing urban storm runoff quality in Dhahran City in Saudi Arabia. Water International 24: 53-58.

Kennedy J. 2007. Changes in Storm Runoff with Urbanization: the Role of Pervious Areas in a Semi-Arid Environment. The University of Arizona, Department of Hydrology and Water Resources: Tucson, AZ; 111.

Kirchner JW, Feng XH, Neal C. 2000. Fractal stream chemistry and its implications for contaminant transport in catchments. Nature 403: 524-527.

Klein RD. 1979. Urbanization and Stream Quality Impairment. Water Resources Bulletin 15: 948-963.

Lajtha K, Schlesinger WH. 1988. The Biogeochemistry of Phosphorus Cycling and Phosphorus Availability Along a Desert Soil Chronosequence. Ecology 69: 24-39.

Lee JH, Bang KW, Ketchum LH, Choe JS, Yu MJ. 2002. First flush analysis of urban storm runoff. Science of the Total Environment 293: 163-175.

Lee JH, Yu MJ, Bang KW, Choe JS. 2003. Evaluation of the methods for first flush analysis in urban watersheds. Water Science and Technology 48: $167-176$.

Lee H, Lau SL, Kayhanian M, Stenstrom MK. 2004. Seasonal first flush phenomenon of urban stormwater discharges. Water Research 38: 4153-4163.

Lerner DN. 2002. Identifying and quantifying urban recharge: a review. Hydrogeology Journal 10: 143-152.

Lewis DB, Grimm NB. 2007. Hierarchical regulation of nitrogen export from urban catchments: Interactions of storms and landscapes. Ecological Applications 17: 2347-2364.

Lohse KA, Hope D, Sponseller R, Allen JO, Grimm NB. 2008. Atmospheric deposition of carbon and nutrients across an and metropolitan area. Science of the Total Environment 402: 95-105.

Loik ME, Breshears DD, Lauenroth WK, Belnap J. 2004. A multi-scale perspective of water pulses in dryland ecosystems: climatology and ecohydrology of the western USA. Oecologia 141: 269-281. DOI: $10.1007 / \mathrm{s} 00442-004-1570-y$

Maestre A, Pitt R. 2006. Identification of Significant Factors Affecting Stormwater Quality Using the NSQD. In Stormwater and Urban Water Systems Modeling Proceedings, Monograph 14, James W, Irvine KN, McBean EA, Pitt RE (eds). CHI (Computational Hydraulics International): Guelph, Ontario; 287-326.

McIntyre RES, Adams MA, Grierson PE. 2009. Nitrogen mineralization potential in rewetted soils from a semi-arid stream landscape, northwest Australia. Journal of Arid Environments 73: 48-54.

Mendez A, Goodrich DC, Osborn HB. 2003. Rainfall point intensities in an air mass thunderstorm environment: Walnut Gulch, Arizona. JAWRA Journal of the American Water Resources Association 39: 611-621.

Norman LM, Feller M, Guertin DP. 2009. Forecasting urban growth across the United States-Mexico border. Computers Environment and Urban Systems 33: 150-159.
Norra S, Fjer N, Li F, Chu X, Xie X, Stuben D. 2008. The influence of different land uses on mineralogical and chemical composition and horizonation of urban soil profiles in Qingdao, China. Journal of Soils and Sediments 8: 4-16.

Obermann M, Rosenwinkel KH, Tournoud MG. 2009. Investigation of first flushes in a medium-sized mediterranean catchment. Journal of Hydrology 373: 405-415.

Osborn HB, Lane L. 1969. Precipitation-Runoff Relations for Very Small Semiarid Rangeland Watersheds. Water Resources Research 5: 419-\&. Parks SJ, Baker LA. 1997. Sources and transport of organic carbon in an Arizona river-reservoir system. Water Research 31: 1751-1759.

Passeport E, Hunt WF. 2009. Asphalt Parking Lot Runoff Nutrient Characterization for Eight Sites in North Carolina, USA. Journal of Hydrologic Engineering 14: 352-361.

Paul MJ, Meyer JL. 2001. Streams in the urban landscape. Annual Review of Ecology and Systematics 32: 333-365.

Pitt RE, Maestre A, Hyche H, Togawa N. 2008. The Updated Stormwater Quality Database (NSQD), Version 3. Proceedings of the Water Environment Federation 2008: 1007-1026.

Pool DR. 2005. Variations in climate and ephemeral channel recharge in southeastern Arizona, United States. Water Resources Research 41: W11403. DOI: 10.1029/2004WR003255

Renard KG, Nichols MH, Woolhiser DA, Osborn HB. 2008. A brief background on the U.S. Department of Agriculture Agricultural Research Service Walnut Gulch Experimental Watershed. Water Resources Research. 44: W05S02.

Robertson FN. 1989. Arsenic in ground-water under oxidizing conditions, southwest United States. Environmental Geochemistry and Health 11: 171-185.

Rose S. 2007. The effects of urbanization on the hydrochemistry of base flow within the Chattahoochee River Basin (Georgia, USA). Journal of Hydrology 341: 42-54. DOI: 10.1016/j.jhydrol.2007.04.019

Rose S, Peters NE. 2001. Effects of urbanization on streamflow in the Atlanta area (Georgia, USA): a comparative hydrological approach. Hydrological Processes 15: 1441-1457.

Sall J, Creighton L, Lehman A. 2007. JMP start statistics a guide to statistics and data analysis using JMP. SAS Institute: Cary, NC.

Scanlon BR, Keese KE, Flint AL, Flint LE, Gaye CB, Edmunds WM, Simmers I. 2006. Global synthesis of groundwater recharge in semiarid and arid regions. Hydrological Processes 20: 3335-3370.

Schlesinger WH. 1997. Biogeochemistry: an analysis of global change. Academic Press: San Diego, Calif.

Schueler TR, Fraley-McNeal L, Cappiella K. 2009. Is Impervious Cover Still Important? Review of Recent Research. Journal of Hydrologic Engineering 14: 309-315. DOI: 10.1061/(ASCE)1084-0699(2009)14:4(309)

Seager R, Ting MF, Held I, Kushnir Y, Lu J, Vecchi G, Huang HP, Harnik N, Leetmaa A, Lau NC, Li CH, Velez J, Naik N. 2007. Model projections of an imminent transition to a more arid climate in southwestern North America. Science 316: 1181-1184.

Serrat-Capdevila A, Valdes JB, Perez JG, Baird K, Mata LJ, Maddock T. 2007. Modeling climate change impacts and uncertainty on the hydrology of a riparian system: The San Pedro Basin (Arizona/Sonora). Journal of Hydrology 347: 48-66. DOI: 10.1016/j.jhydrol.2007.08.028

Shariatmadari H, Shirvani M, Jafari A. 2006. Phosphorus release kinetics and availability in calcareous soils of selected arid and semiarid toposequences. Geoderma 132: 261-272.

Shaver E, Horner R, Skupien J, May C, Ridley G. 2007. The Fundamentals of Urban Runoff Management: Technical and Institutional Issues. North American Lake Management Society and U.S. Environmental Protection Agency: Madison, WI; 327.

Shuster WD, Bonta J, Thurston H, Warnemuende E, Smith BJ. 2005. Impacts of impervious surface on watershed hydrology: A review. Urban Water Journal 2: 263-275.

Shuster WD, Pappas E, Zhang Y. 2008. Laboratory-scale simulation of runoff response from pervious-impervious systems. Journal of Hydrologic Engineering 13: 886-893.

Smith JA, Baeck ML, Meierdiercks KL, Nelson PA, Miller AJ, Holland EJ. 2005. Field studies of the storm event hydrologic response in an urbanizing watershed. Water Resources Research 41: W10413. DOI: 10.1029/2004WR003712

Soller J, Stephenson J, Olivieri K, Downing J, Olivieri AW. 2005. Evaluation of seasonal scale first flush pollutant loading and implications for urban runoff management. Journal of Environmental Management 76: 309-318.

Soonthornnonda P, Christensen ER, Liu Y, Li J. 2008. A washoff model for stormwater pollutants. Science of the Total Environment 402: 248-256.

Stone JJ, Nichols MH, Goodrich DC, Buono J. 2008. Long-term runoff database, Walnut Gulch Experimental Watershed, Arizona, United States. Water Resources Research 44: W05S05. DOI: 10.1029/2006WR005733 
Tadayon S. 1995a. Quality of surface water and ground water in the proposed artificial-recharge project area, Rillito Creek Basin, Tucson, Arizona, 1994. U.S. Geological Survey Water-Resources Investigations, Report 95-4270: 26.

Tadayon S. 1995b. Quality of water and chemistry of bottom sediment in the Rillito Creek Basin, Tucson, Arizona, 1992-93. U.S. Geological Survey Water-Resources Investigations, Report 94-4114: 57.

Tiefenthaler LL, Stein ED, Schiff KC. 2008. Watershed and land usebased sources of trace metals in urban storm water. Environmental Toxicology and Chemistry 27: 277-287.

Unland HE, Houser PR, Shuttleworth WJ, Yang Z-L. 1996. Surface flux measurement and modeling at a semi-arid Sonoran Desert site. Agricultural and Forest Meteorology 82: 119-153.

U.S. EPA. 2002. Method 1604: Total Coliforms and Escherichia coli in Water by Membrane Filtration Using a Simultaneous Detection Technique (MI Medium). Environmental Protection Agency Publication 821-R-02-024: Washington D.C. Retrieved from: http://www.epa.gov/ nerlcwww/1604sp02.pdf

Walsh CJ, Roy AH, Feminella JW, Cottingham PD, Groffman PM, Morgan RP. 2005. The urban stream syndrome: current knowledge and the search for a cure. Journal of the North American Benthological Society 24: 706-723.
Welter JR, Fisher SG, Grimm NB. 2005. Nitrogen transport and retention in an arid land watershed: Influence of storm characteristics on terrestrial-aquatic linkages. Biogeochemistry 76: 421-440.

Wenger SJ, Roy AH, Jackson CR, Bernhardt ES, Carter TL, Filoso S, Gibson CA, Hession WC, Kaushal SS, Marti E, Meyer JL, Palmer MA, Paul MJ, Purcell AH, Ramirez A, Rosemond AD, Schofield KA, Sudduth EB, Walsh CJ. 2009. Twenty-six key research questions in urban stream ecology: an assessment of the state of the science. Journal of the North American Benthological Society 28: 1080-1098.

Westerhoff P, Anning D. 2000. Concentrations and characteristics of organic carbon in surface water in Arizona: influence of urbanization. Journal of Hydrology 236: 202-222.

Westerlund C, Viklander M, Backstrom M. 2003. Seasonal variations in road runoff quality in Lulea, Sweden. Water Science and Technology 48: 93-101.

Wilson LG, Matlock WG, Jacobs KL. 1998. Hydrogeologic uncertainties and policy implications: The Water Consumer Protection Act of Tucson, Arizona, USA. Hydrogeology Journal 6: 3-14. DOI: 10.1007/ s100400050129

Xie H, Zhou X, Hendrickx JMH, Vivoni ER, Guan H, Tian YQ, Small EE. 2006. Evaluation of Nexrad Stage III Precipitation Data Over a Semiarid Region. JAWRA Journal of the American Water Resources Association 42: 237-256. DOI: 10.1111/j.1752-1688.2006.tb03837.x 